Türk Turizm Araştırmalari Dergisi
2021, 5(2): $851-876$.
ISSN: $2587-0890$ Dergi web sayfasi: $\underline{\text { https://www.tutad.org }}$

\title{
Yabancı Turistlerin Tipolojilerine Göre Seyahat Sağlık Risk Algıları ve Önleme Davranışlarının Belirlenmesi*,**
}

\author{
Öğr. Gör. Dr. Ayşen ACUN KÖKSALANLAR, Bursa Uludağ Üniversitesi, İznik Meslek \\ Yüksekokulu, Bursa, e-posta: aysenacun@uludag.edu.tr \\ ORCID: https://orcid.org/0000-0002-9551-0702 \\ Prof. Dr. Ahmet KÖROĞLU, Balıkesir Üniversitesi, Turizm Fakültesi, Balıkesir, e-posta: \\ akoroglu@balikesir.edu.tr \\ ORCID: https://orcid.org/0000-0002-6694-4667
}

\section{Öz}

Bu çalışmanın amacı Türkiye'ye gelen yabancı turistlerin tatillerinden bekledikleri faydaların belirlenmesi ve belirlenen faydalara göre pazar bölümlerinin oluşturulmasıdır. Türkiye'ye gelen yabancı turistlerin Türkiye ile ilgili sağlık risk algılarının tespit edilmesi araştırmanın diğer amacını oluşturmaktadır. Ayrıca yabancı turistlerin seyahate çıkmadan önce sağlık ile ilgili aldıkları önlemler de belirlenmek istenmiştir. Bu doğrultuda ilgili literatür tarandıktan sonra veri toplama aracı olarak anket formu kullanılmıştır. Anketler Almanca, Rusça, İngilizce ve Türkçe dillerinde, 2019 Haziran-Ekim tarihleri arasında ve en fazla turist giriş çıkışının olduğu İstanbul, Antalya, İzmir havaalanlarında uygulanmıştır. 851 yabancı turiste ulaşılmış ve anket soruları yüz yüze sorulmuştur. Çalışmada verilerin analizinde aritmetik ortalama, medyan, mod ve standart sapma gibi tanımlayıcı istatistiklerden yararlanılmıştır. Ayrıca faktör analizi, kümeleme analizi, ayırma analizi gibi analizlerden de yararlanılmışır. Çalışmada yapılan faktör analizi sonucunda 6 fayda faktörü elde edilmiştir. Elde edilen 6 faktöre kümeleme analizi uygulanmıştır ve sonucunda 4 pazar bölümü ortaya çıkmıştır. Birinci pazar bölümü "Deniz-Güneş-Kum Faydası Arayan Turistler", ikinci pazar bölümü "Kültürel Fayda Arayan Turistler", üçüncü pazar bölümü "İletişim ve Ulaşım Kolaylığı İsteyen Turistler", dördüncü pazar bölümü ise "Ekonomiklik, Güvenlik ve Rahatlık Arayan Turistler" şeklinde adlandırılmıştır. Ayrıca turistlerin Türkiye'yi sağlık riski açısından güvenli buldukları belirlenmiştir. Turistlerden Türkiye'de algıladıkları sağlı riskini derecelendirmeleri istendiğinde turistlerin çok büyük çoğunluğunun en az risk seçeneğini işaretledikleri belirlenmiştir. Turistlerin büyük çoğunluğunun Türkiye'ye gelmeden önce sağlık tavsiyesi almadığı belirlenmiştir.

*Bu çalışma Ayşen Acun Köksalanlar'ın 'Yerli ve Yabancı Turistlerin Tipolojilerine Göre Seyahat Sağlık Risk Algıları ve Önleme Davranışlarının Belirlenmesi' adlı doktora tezinden türetilmiştir.

**Bu çalışma Balıkesir Üniversitesi Rektörlüğü Bilimsel Araştırma Projeleri Birimi tarafından BAP 2019/006 nolu proje ile desteklenmiştir.

Anahtar Kelimeler: Pazar Bölümlendirme, Sağlık Risk Algısı, Alınan Önlemler, Turizm.

Makale Gönderme Tarihi: 02.03.2021

Makale Kabul Tarihi: 05.06.2021

\section{Önerilen Atıf:}

Acun Köksalanlar, A. ve Köroğlu, A. (2021). Yabancı Turistlerin Tipolojilerine Göre Seyahat Sağlık Risk Algıları ve Önleme Davranışlarının Belirlenmesi, Türk Turizm Araştırmaları Dergisi, 5(2): 851-876.

(C) 2021 Türk Turizm Araştırmaları Dergisi. 


\title{
Journal of Turkish Tourism Research
2021, 5(2): 851-876.
DOI: 10.26677/TR1010.2021.742 \\ RESEARCH PAPER
}

\section{Travel Health Risk Perceptions of Foreign Tourists by Their Typologies and Determination of Prevention Behavior}

\author{
Dr. Ayşen ACUN KÖKSALANLAR, Bursa Uludağ University, İznik Vocational School, Bursa, e- \\ mail: aysenacun@uludag.edu.tr \\ ORCID: https://orcid.org/0000-0002-9551-0702
}

Prof. Dr. Ahmet KÖROĞLU, Balıkesir University, Faculty of Tourism, Balıkesir, e-mail: akoroglu@balikesir.edu.tr ORCID: https://orcid.org/0000-0002-6694-4667

\begin{abstract}
This study aims to determine the benefits expected by foreign tourists visiting Turkey from their holidays. We aimed to create market segmentation for foreign tourists by the determined benefits. Another aim of the study is to identify the health risk perceptions of foreign tourists visiting Turkey about Turkey. In this study, it was also aimed to determine the health-related measures taken by foreign tourists before leaving on vacation. In this context, the concepts of market segmentation and health risk perception were examined in the literature section of the study in detail. In the application section of the study, on the other hand, the questionnaire form was used as a data collection tool. The questionnaires were conducted in German, Russian, English, and Turkish languages between June-October 2019 in İstanbul, Antalya, and İzmir airports with the highest number of tourist entrance and exit. We have reached 851 tourists and we have asked the questionnaire items using the face-to-face method. In the study, descriptive statistics such as arithmetic mean, median, mode, and standard deviation were used to analyze the data. In addition, analyzes such as factor analysis, cluster analysis, and discriminant analysis were also used. Six benefit factors were determined as a result of the analysis made in the study. Cluster analysis was applied to six factors determined and four market segments were obtained in the sequel. The names of the four market segments were decided as follows respectively: "Tourists Seeking for Sea-Sand-Sun Benefit", "Tourists Seeking for Cultural Benefit", "Tourists Demanding Means of Communication and Transportation, and "Tourists Seeking for Economic, Safety, and Comfort". Besides, it was found that tourists consider Turkey safe in terms of health risks. When tourists were asked to rate the health risk they perceive in Turkey, it was seen that the vast majority of tourists checked the option of least risk. It was determined that the vast majority of tourists did not receive any health advice before arriving in Turkey.
\end{abstract}

Keywords: Market Segmentation, Health Risk Perception, Measures Taken, Tourism.

Received: 02.03.2021

Accepted: 05.06.2021

Suggested Citation:

Acun Köksalanlar, A. and Köroğlu, A. (2021). Travel Health Risk Perceptions of Foreign Tourists by Their Typologies and Determination of Prevention Behavior, Journal of Turkish Tourism Research, 5(2): 851-876.

(C) 2021 Türk Turizm Araştırmaları Dergisi. 


\section{Gíriş}

Pazar bölümlendirme tüketicilerin özelliklerini ve ihtiyaçlarını bilmek için kullanılan ve hem yöneticiler hem de araştırmacılar arasında yaygın olarak tartışılan bir kavram haline gelmiştir (Blattberg ve Sen, 1974: 17; Kuo, Akbaria ve Subroto, 2012). Bu kadar önemli bir kavram olmasının nedeni tüketici gruplarının birbirinden farklı istek, ihtiyaç ve beklentilere sahip olmasıdır. Özellikle farklı turist gruplarının yer aldığ 1 turizm sektöründe de pazar bölümlendirme kavramı oldukça önemlidir. Çünkü belirli bir turizm ürününün turizme katılan tüm kişilerin zevk ve isteklerine göre bir arada aynı niteliklere sahip olması düşünülemez (Hacıoğlu, 2014: 34). Bu nedenle pazar bölümlendirme, turistlerin belirgin özelliklerini anlamak ve pazarlama stratejileri geliştirmek için yaygın olarak kullanılmaktadır. Turizmde pazar bölümlendirme, bir pazarı ayrı deneyimler veya pazarlama hizmet karmaları gerektirebilecek farklı turist gruplarına bölme işlemidir şeklinde tanımlanmaktadır (Bloom, 2004: 723). Turizm sektöründe pazar bölümlendirme ile turist gruplarının ne istedikleri, tatillerinden hangi faydaları bekledikleri, tatillerinde ihtiyaç duyabilecekleri hizmetlerin neler gibi soruların cevapları belirlenebilir. Turistlerin ne istedikleri, neye ihtiyaç duydukları ve beklentilerinin ne olduğunun bilinmesi turizm yöneticileri ve pazarlamacıları için önemli olmaktadır. Turistlerin beklentilerinin ne olduğunun bilinmesi hem onların daha mutlu olmasına hem de turizm sektörünün geliştirilmesine katkı sağlayabilir. Bu gibi nedenlerden dolayı pazar bölümlendirmenin önemi ortaya çıkmaktadır.

Hem turizm sektörünün soyut olma, ayrılmazlık, değişkenlik gibi özelliklerinden hem de salgın, doğal afet, terör gibi faktörlerden etkilenmesinden dolayı turizm sektöründe algılanan risk daha fazla olabilmektedir. Turistler güvenli olmadığını düşündükleri yerlere gitme eğiliminde olmamaktadırlar (Law, 2006; Qi, Gibson ve Zhang, 2009; Hajibaba vd., 2015; Dayour, Park ve Kimbu, 2019). Sadece terör gibi turistlerin can güvenliğini tehdit eden faktörler değil sağllk riski gibi turistleri endişelendiren faktörler de bulunmaktadır. Geçmiş dönemlerde çeşitli salgın hastalıkların turistleri ve turizm talebini etkilediği görülmektedir (Peattie, Clarke ve Peattie, 2005; Moreira, 2008; Jonas vd., 2011). Özellikle içinde bulunduğumuz koronavirüs salgınında da turizm durma noktasına gelmiştir. Hem hükümetlerin aldıkları kısıtlayıcı kararlar hem de turistlerin salgın hastalığa yakalanma korkusu gibi nedenlerden dolayı seyahat etmedikleri görülmektedir. Bu durum sağlık risk algısı konusunun önemini ortaya çıkarmaktadır. Bu nedenle turistlerin Türkiye hakkında sağlık risk algılarının neler olduğunun ve bunu önlemek için ne gibi davranışlarda bulunduklarının bilinmesi oldukça önemlidir. Bu davranışların bilinmesi ile turizm yöneticileri ve pazarlamacıları o davranışlara uygun tanıtım faaliyetleri geliştirebilirler. $\mathrm{Bu}$ nedenle çalışmanın amacı turistlerin tatillerinden bekledikleri faydaların belirlenmesi, turistlerin sağlık risk algılarının ve önleme davranışlarının tespit edilmesidir.

\section{LIITERATÜR}

Pazar bölümlendirme, müşterilerin farklı özelliklerini anlamak ve pazarlama stratejileri geliştirmek için yaygın bir şekilde kullanılmaktadır (Bloom, 2004). Bölümlendirme kavramı pazarlama sorunlarını çözmek ve farklı yönetim sorunlarını ele almak için de kullanılmaktadır (Hsu ve Kang, 2007). Bölümlendirme fikri, pazarı benzer satın alma davranışları olan insan gruplarına ayırmaktır çünkü insanlar tercihleri, istekleri ve ihtiyaçları bakımından homojen değildir (Hsu ve Kang, 2007; Legoherel, Hsu ve Dauce, 2015).

Literatürde pazar bölümlendirme ile ilgili yapılan tanımlara bakıldığında ilk tanımın Smith (1956) tarafından yapıldığı görülmektedir. Smith'e (1956) göre "pazar bölümlendirme, pazarın talep tarafındaki gelişmelerini temel almaktadır ve tüketici veya kullanıcı gereksinimleriyle ürün 
sunumlarının daha düzgün uyumlaştırılması ve pazarlanması çabasıdır" (Aktaran: Trindade, Dias ve Ambrosio, 2017). Pazar bölümlendirme uzun zamandır modern pazarlamanın en temel kavramlarından biri olarak kabul edilmiştir. Wendell Smith'in öncül yazısından bu yana geçen zamanda pazarlama literatüründe ve pratiğinde bölümlendirme önemli bir kavram haline gelmiştir (Wind, 1978). Wind (1978), Dickson, (1982), Elrod ve Winer (1982), Dickson ve Ginter, (1987) gibi yazarlar gelişmeye başlayan bölümlendirme literatürüne önemli katkılar sağlamışlardır.

Kotler ve diğerlerine göre (1999: 379) pazar bölümlendirme, büyük bir pazarın farklı pazarlama politikaları gerektirebilecek farklı ihtiyaçlara, özelliklere veya davranışa sahip tüketicilerin parçalara bölünmesini içeren bir stratejidir. Ayrıca pazar bölümlendirme yoluyla şirketler büyük, heterojen pazarları benzersiz ihtiyaçlara uygun ürün ve hizmetler ile daha verimli bir şekilde ulaşabilecekleri daha küçük bölümlere ayırmaktadır. Pazar bölümlendirme, büyük heterojen pazarların benzer ihtiyaçlara ve yanıt verme yeteneğine sahip, daha küçük, homojen alt gruplara veya işlere bölünmesi sürecidir (Kinnear ve Bernhardt, 1990: 103). Wyner (1995) pazar bölümlendirmesini farklı davranılması gereken farklı müşteri gruplarının tanınması olarak tanımlamıştır. Tenekecioğlu ve Ersoy (2007) ise pazar bölümlendirmeyi “başlangıçta müşteriyi temel alan, rakiplere karşı işletmenin güçlü yönlerini ortaya çıkaran ve işletmenin kaynaklarını maksimum kullanmayı hedefleyen analitik bir süreç" olarak tanımlamışlardır.

Pazar bölümlendirme, tüketicilerin zevk ve tercihlerinin çeşitliliğini anlamak ve farklı turizm ürünleri ve hizmetleri için niş pazarları belirlemek için yaygın olarak kullanılmaktadır (Rid, Ezeuduji ve Pröbstl-Haider, 2014). Pazar bölümlendirme kitle pazarlamasına göre çeşitli avantajlar sunmaktadır. Şirket ürünlerini veya hizmetlerini, kanallarını ve iletişim programlarını yalnızca en iyi hizmet verebilecek tüketicilere doğru hedefleyerek daha verimli bir şekilde pazarlayabilir. Ayrıca şirket ürünlerini, fiyatlarını ve programlarını dikkatlice tanımlanmış bölümlerin ihtiyaçlarına göre hassas bir şekilde ayarlayarak daha etkin bir şekilde pazarlayabilir. Daha az rakip bu pazar bölümüne odaklanıyorsa, şirket daha az rakiple karşılaşabilir (Kotler vd., 1999: 381).

Pazar bölümlendirmenin amacl, mevcut pazar bölümlerinin birbirinden ayırıcı niteliklerini belirlemek, bu niteliklere göre pazar bölümlerini saptamak, her bölümün büyüklügünü ve değerini tespit etmek, rakiplerin pazardaki durumlarını incelemek ve yeterince hizmet edilmeyen pazar bölümlerini seçmektir. Tüm bu faaliyetleri işletmeler, kendileri açısından en uygun pazar fırsatlarını yakalayabilmek için yapmaktadır (Altunışık, 2009).

Shoemaker (1994) 942 ABD'li turiste seyahat faydası değişkenini kullanarak yaptığı çalışmada macera ve eğitim odaklı gezginler, oyun ve eğlence odaklı gezginler, kaçış ve aile odaklı gezginler şeklinde üç turist tipi belirlemiştir. Waryszak ve Kim (1994), 84 Koreli turiste psikografik değişkenler kullanarak yaptıkları çalışmada bilgi arayanlar, maceracılar, deneyim yaşayanlar, zevk arayanlar, kanaat önderleri şeklinde 5 turist tipi belirlemiştir. Oh, Uysal ve Weaver (1995) tarafından 1030 Avustralyalı katılımcıya seyahat motivasyonu değişkeni kullanılarak yapılan çalışmada, spor etkinlik arayanlar, güvenlik konfor arayanlar, kültür tarih arayanlar, yenilik macera arayanlar ve lüks arayanlar şeklinde 5 turist tipi belirlenmiştir. Palacio ve McCool (1997), Belize'ye gelen 206 turiste fayda değişkeni kullanılarak yaptıkları çalışmada doğa hayalperest, ekoturist, rahat doğacılar, pasif oyuncular şeklinde 4 turist tipi belirlemişlerdir. Kesic ve Piri Rajh (2003) tarafından yaşam tarzı değişkeni kullanılarak 628 aileye yapılan çalışmanın sonucunda rahat, geleneksel, modern, endişeli, hedonist şeklinde 5 pazar bölümü belirlenmiştir. Kerstetter, Hou ve Lin (2004), Tayvan'a giden 450 turiste motivasyon ve davranış değişkeni kullanarak yaptıkları çalışmada deneyim turistleri, öğrenen turistler, ekoturistler şeklinde 3 turist tipi belirlemişlerdir. Özel'in (2010) güdülere dayalı değişken kullanarak 3915 yerli turiste yaptığ 1 çalışmanın sonucunda rahatlama arayanlar, çekingenler, başarı arayanlar, aile düşkünleri, spor 
tutkunları, kaçış arayanlar şeklinde 6 turist tipi belirlemiştir. Albayrak ve Caber (2018) tarafından motivasyon değişkeni kullanılarak 375 turiste yapılan çalışmanın sonucunda aktif tatilciler, isteksiz tatilciler, orta tatilciler ve mücadele arayan tatilciler şeklinde 4 turist tipi belirlenmiştir.

\section{Fayda Bölümlendirme}

Fayda bölümlendirme, pazarın aranan faydalara dayanarak bölümlere ayrıldığı bir tekniktir. Pazarda bölümlere ayırmanın temel nedeni, insanların bir ürün veya hizmeti tüketirken aradıkları farklı faydalardan kaynaklanmaktadır (Haley, 1968). Pazardaki herhangi bir ürün veya hizmet, tüketici ihtiyaçlarını ve isteklerini karşılamaya yönelik bazı temel faydaları içermelidir. Tüketici tarafından aranan faydaları anlamak, tüketici beklentilerini karşılayabilecek yeni ürün veya hizmetleri değiştirmek veya geliştirmek için önemlidir. Haley (1968), fayda bölümlendirmesini "pazar bölümlerini tanımlayıcı faktörlerden ziyade nedensel faktörlerle tanımlamanın mümkün olduğu pazar bölümlendirmesi" olarak tanımlamıştır. Fayda bölümlendirmesinin pazarları bölümlere ayırmanın en iyi yollarından biri olduğu ve pazarlamacılar ve araştırmacılar tarafından geniş çapta kabul gören bir yaklaşım olduğu ve "demografik", "coğrafi" vb. gibi diğer bölümlendirme değişkenleri ile birlikte kullanılabileceği savunulmaktadır. Ayrıca fayda bölümlendirme hedef tüketicilerin ilgisi ile ilgilidir ve pazar bölümü için demografik ve yaşam tarzı özellikleri gibi tanımlayıcı değişkenlerden daha mükemmel bir ölçü olarak kabul edilmektedir (Park vd., 2011; Arunachalam ve Kumar, 2018). Haley, 1968 yılında gelecekteki satın alma davranışının coğrafi, demografik veya hacme dayalı bölümlendirme gibi geleneksel pazar bölümlendirme tekniklerinden daha iyi anlaşılmasını ve öngörülmesini sağlayacak bir yöntem geliştirmek amacıyla fayda bölümlendirmesini geliştirmiştir. Böylece Haley pazar bölümlerini nedensel faktörlerle belirlemeye yönelik bir teknik olarak fayda bölümlendirmesini getirmiştir (Haley, 1968: 31). Haley'e (1968) göre, bu bölümlendirme yaklaşımının arkasındaki mantık, tüketicilerin aradığı faydaların gerçek pazar bölümlerinin varlığının temel nedenleri olduğu ve tüketicilerin davranışlarını demografik ve coğrafi gibi diğer tanımlayıcı değişkenlerden daha doğru belirlediğidir.

Fayda bölümlendirme yaklaşımı, tüketici değer sistemlerini, tüketicinin ilgilenilen ürün kategorisindeki çeşitli markalar hakkında ne düşündüğü ile birlikte detaylı bir şekilde ölçmeye dayanır (Engel, Fiorill ve Cayley, 1971). Fayda bölümlendirmesi basit olarak, müşterilerin aynı ürünleri farklı nedenlerden dolayı satın aldıkları ve farklı ürün özelliklerine farklı değerler yükledikleri varsayımı üzerine dayanmaktadır (Birdir, 2009).

Seyahat ve turizmde fayda bölümlendirmesine olan yoğun ilginin nedeni, karar verme sürecinde her zaman kritik bir değişken olarak gösterilen turistlerin motivasyonlarına odaklanmasıdır (Frochot, 2005). Fayda temelli bölümlendirme yaklaşımı, turizm piyasasına dayalı bölümlendirmenin anlaşılmasının turistik ürünlerin geliştirilmesinde ve desteklenmesinde kritik öneme sahip olduğunu açıklayan araştırmacılar tarafından yaygın olarak kullanılmaktadır (Chen, 2000).

Birdir (2009) yaptığı çalışmada güvenlik ve konfor faydaları arayanlar, güneş-deniz-kum faydaları arayanlar olarak iki grup belirlemiştir. Eusébio ve diğerleri (2017), çalışmasında faydaya göre 3 grup belirlemiştir. Frochot (2005) fayda temelli bölümlendirme çalışmasında aktifler, sakinler, dış mekanlara ilgi duyanlar, kırsallar şeklinde 4 grup belirlemiştir. Kuo, Akbaria ve Subroto (2012), pasif turistler, öğrenen turistler, algısı yüksek turistler, yüksek varyasyonlu turistler şeklinde 4 grup belirlemiştir. Molera ve Albaladejo (2007) çalışmasında kırsal turizmde aranan faydaya göre beş grup (aktif kırsal turist, aile kırsal turist, sakin kırsal turist, kırsal yaşam turist, kırsal konaklama turist) belirlemiştir. Palacio ve McCool (1997) ekoturistlerin aradıkları faydalara göre bölümlendirme çalışmasında doğaya kaçanlar, ekoturistler, rahat natüralistler, 
pasif oyuncular şeklinde dört grup belirlemiştir. Yannopoulos ve Rotenberg (2000) tarafından yapılan çalışmada kültürel beğeniye sahip, kişisel güvenlikleri ve konforları ile ilgilenen turistler, aktif metaryalistler, eğlence ve konfor arayan turistler, kültürel-tarihi yerler ve alışveriş imkanları sunan yerlerle ilgilenen turistler, eğlence-tema parkları ve gece hayatı şeklinde eğlence sunan yerlerle ilgilenen turistler şeklinde beş kümeye ayrılmıştır. Jang ve diğerleri (2002) yaptığ çalışmada turistleri aranan faydaya göre yenilik doğa arayanlar, kaçış rahatlama arayanlar, aile açı hava etkinliği arayanlar şeklinde bölümlere ayırmıştır.

\section{Sağlık Risk Algısı}

Sağlık riski, kişilerin seyahat halindeyken hastalanma veya belirli hastalıklara yakalanma olasılığıdır (Adam, 2015). Turistlerin büyük çoğunluğu sağlık krizinin bir parçasını oluşturmaktadır. Ekolojik baskılar da riski arttırmaktadır. Boş zaman seyahatleri ile turizm bölgeleri daha kalabalık olmaktadır. Aynı zamanda daha uzak yerlere giden macera seyahatlerine de ilgi artmaktadır. Bu faktörlerin tümü sağlık tehditlerini kolaylaştırmaktadır. Turizm ile ilgili hastalıklar, kazalar ve ölümler, gelişmekte olan ülkelerde, gelişmiş ülkelerden 50 kat daha yüksektir. Ormansızlaşma ve küresel ısınma da sağllğg tehdit etmektedir. Örneğin 1976 'dan bu yana en çok keşfedilen veya ormansızlaştırılan tropik bölgelerden gelen üç düzineden fazla hastalık keşfedilmiştir (Ritcher, 2003).

Wilks (2006) tarafından yorumlandığı üzere sağlık riski, turistlerin ve ev sahibi toplulukların emniyet ve güvenliğini tehlikeye atabilecek faktörlerden biridir. Dünya Sağllk Örgütü (2005) bu risk türünü uluslararası seyahatlerle ilişkilendirmekte ve risk seviyesinin turistlerin özellikleri, seyahat davranışları ve varış yerindeki çevresel koşullar tarafından belirlendiğini vurgulamaktadır. 20. yüzyıl boyunca tıptaki büyük ilerlemeye ve yeni binyılın başlangıcına rağmen, çağdaş turist hala seyahatin doğasının ayrılmaz bir parçası olan sağlık risklerine karşı hassastır. Seyahat ederken turistler yeni deneyimlere ve yeni çeşitli kültürel, psikolojik, fizyolojik, duygusal, çevresel ve sağlık sorunlarına maruz kalmaktadır. Bu sağlık sorunları aynı zamanda turistlerin yaş, kültür, ırk, sosyal statü, eğitim seviyesi gibi kişisel özelliklerine de bağlıdır. Bu sorunlara Cossar (2003) rakım, iklim koşulları, radyasyon, hijyen, genel hastalıklar gibi destinasyondaki alışılmamış çevresel şartları da eklemiştir (Aktaran: Jonas vd., 2011). Aynı zamanda artan insan hareketliliği de bulaşıcı hastalıkların dünya çapında yayılmasında olumsuz sonuçlara yol açmaktadır (Svensson vd., 2018). Artan dünya nüfusu, büyük çapta hızlı uluslararası seyahatler ve insanın doğada hastalık etkenlerine maruz kalmaları bulaşıcı hastalıkların ortaya çıkmasına veya tekrarlamasına neden olmaktadır (Ritcher, 2003). Seyahat, bulaşıcı hastalıkların yayılması ile yakından ilişkilidir. Dünya Turizm Örgütü 2017 yılında, dünya genelinde seyahat eden turist sayısının, bir önceki yıla göre 46 milyon artış gösterdiğini ve 1235 milyar kişiye ulaştığını belirtmiştir. Seyahatle ilgili hastalıklar, bulaşıcı hastalıklara yakalanma riski ve son yıllarda uluslararası seyahatlerde görülen artış, bulaşıcı hastalıkların yayılmasına neden olabilmektedir (Ghazali vd., 2018).

Algılanan risk birçok sağlık davranışı teorisindeki merkezi bir yapıyı temsil etmektedir ve sıklıkla algılanan olasılık, algılanan ihtimal, duyarlılık veya kırılganlık olarak adlandırılmaktadır. Menon, Raghubir ve Agrawal (2008), seyahat risk algısını, belirlenen bir süre zarfında seyahat sağlığı ve güvenliği ile ilgili olumsuz bir olayın gerçekleşebilme olasılığının değerlendirilmesi olarak tanımlamaktadır. Bulaşıı hastalıklara yakalanma veya seyahat ederken hastalanma gibi sağlık risklerinin olasılığı tüm yerler için yaygın olduğu göz önüne alındığında, destinasyonlara bakılmaksızın turistlerin genel sağlık riski algılarını incelemek gerekmektedir (Aktaran: Chien vd., 2017). Çünkü turistlerde sağlık problemlerine sık rastlanmaktadır. Bu nedenle önleyici tedbirlerin ne olduğunu bilmek sağlık risklerini bilmek için önemlidir (Steffen vd., 2003). 
Literatürde turistlerin sağlık risk algılarını ölçen çeşitli çalışmalara rastlanmıştır. Zimmermann ve diğerleri (2013) tarafından yapılan çalışmada, uzmanlara göre, turistler için belirlenen en yüksek riskler arasında, sivrisinekler, sıtma, kuduz, salgın hastalıklar, cinsel yolla bulaşan hastalıklar vardır. Terörist saldırıları ve aşı ile ilgili hastalıklar en düşük sırada yer almıştır. Uzmanların değerlendirmelerinin aksine, turistler kazaları ve cinsel yolla bulaşan hastalıkları önemli ölçüde daha düşük risk olarak algılamışlardır. Cinsiyet, yaş, destinasyon ve bölgeye bağlı seyahat deneyimi, turistlerin risk algısı üzerinde farklı etkiler yaratmıştır. Kadın katılımcılara nazaran erkek katılımcılar, sivrisinek, sıtma ve kuduz gibi hastalıkların daha çok riskli olduğunu düşünmektedirler. Genç katılımcılarla karşılaştırıldığında, 40 yaşın üzerindeki turistler terörist saldırılarını daha riskli, cinsel yolla bulaşan hastalıkları ise daha düşük riskli bulduklarını belirtmişlerdir. Hamer ve Connor (2004), ABD'li turistlerin seyahatle ilgili sağlık risklerini nasıl algıladıklarını ve uluslararası seyahatleri için nasıl hazırlandıklarını analiz etmiştir. Hamer ve Connor (2004), yaptıkları çalışmada turistlerin yarısından fazlasının yolculuğunu en az bir ay önceden hazırlamış olmasına rağmen, yalnızca \%36'sının seyahat sağlık önerileri almış olduğunu belirlemiştir. Her ne kadar sıtma oranı yüksek bir bölgeye gitseler de turistlerin çoğunluğu (\%73) sıtmayı yüksek sağlık riski olarak algılamış ancak sadece \%46'sı yanına sıtma önleyici ilaçlar almıştır. Turistlerin çoğunluğunun aşıların korunma için etkili olduğuna inanmasına rağmen, çok az kişi (tetanoz için \%11, hepatit A için \%14, hepatit B için \%13 ve sarı ateş için \%5 şeklinde) seyahatleri için aşılanmıştır.

Aziz ve diğerleri (2018) çalışmasında hacıların seyahat öncesi sağlık uygulamalarını araştırmıştır. Umre hacılarının sırasıyla \%60, \%46,3 ve \%46,3'ü seyahat öncesi aşılama, sağlık bilgisi arama ve sağlık muayenesi önemine inanmaktadır. En sık uygulanan seyahat öncesi sağlıkla ilgili davranış, aşılanma $(\% 56,3)$ olmuştur. Katılımcıların yarısından fazlası $(\% 60)$ seyahat öncesi aşılamanın önemine inanmaktadır. Katılımcıların yaklaşık yarısı seyahat öncesi sağlık bilgisi $(\% 46,3)$, sağlık muayenesi $(\% 48,7)$ ve $(\% 52)$ seyahatten önce sadece yaşlıların doktora gitmesi gerektiğini düşünmüşlerdir. Hacılara sağlık risk algıları hakkında soru sorulduğunda, araştırmaya katılanların yalnızca \%30,3'ü umredeyken sağlık riskine maruz kalmayı beklediklerini belirtmişlerdir. Katılımcıların \%15,7'si herhangi bir sağlık riski algılamadığını belirtmiştir. Çalışmaya katılanların yarısından fazlası (\%54) sağlık risklerine maruz kalıp kalmayacağını bilmediğini belirtmiş̧ir. Özel kliniklerin (\%63,9), internetin (\%20) ve turizm şirketlerinin (\%5,5), hacılar için sağlık bilgisi konusunda temel bilgi kaynağı olduğu tespit edilmiştir.

Balaban ve diğerleri (2014), tarafından gerçekleştirilen araştırmada, katılımcıların çoğunluğunun sağlık riski yüksek olan en az bir faaliyete (kırsal alanları ziyaret etmek, hayvanları ele almak, kan veya vücut sıvılarıyla temas, sıtmalı bölgeleri ziyaret etmek) katıldıklarını belirttikleri ifade edilmiştir. Katılımcların \%41'i beklenmeyen sağlık risklerine maruz kaldığını belirtmiştir. Seyahat sırasındaki hastalık (\%27) oranında bildirilmiş̧tir.

Hartjes ve diğerleri (2009), gençlere yönelik seyahat sağlığı bilgisi kaynağının seyahat rehberleri olduğunu belirtmiştir. Katılımcıların en yüksek algıladıkları tehditlerin gıda-su, psikolojik rahatsızlık, kişisel saldırı ve aşırı güneş ışı̆̆ı olduğunu bulmuşlardır. Katılımcılar tarafından seyahat öncesi öneriler hizmet sağlayıcılarından ve seyahat sağlık uzmanlarından alınmıştır. Bunlara ek önlemler aşı ve ilaç olmuştur. Seyahatle ilgili sağlık sorunları, katılımcıların \%25'i tarafından rapor edilmiştir. Bu hastalıklar arasında gastrointestinal, solunum, deri, dang ve sıtma gibi vektör kaynaklı hastalıklar vardır. Gezgin ishali, gelişmekte olan ülkeleri ziyaret ederken sanayileşmiş ülkelerden gelen turistler arasında halen en sık görülen hastalıktır. Fin, İskoç veya Amerikalı turistlerin çoğu özellikle varış noktasına bağlı olarak bazı sağlık şikâyetleri bildirmiştir. Ayrıca, Doğu ve Güney Avrupa'daki paket turlara katılan İskoç turistlerde tespit edildiği gibi, yaz aylarında hastalık oranlarının kış aylarına göre daha yüksek olduğu 
belirtilmiştir. Sıtma, turistler arasında en sık görülen bulaşıcı hastalık olarak belirlenmiştir (Steffen vd., 2003).

Zhang ve diğerleri (2011) tarafından yapılan çalışmada katılımcıların \%40'ının seyahat öncesi tıbbi destek aldığı belirlenmiştir. Katılımcıların sadece \%4,0'ü seyahat sağlık sağlayıcılarından bilgi almıştır. Sıtma riski yüksek ülkelere giden 389 yolcunun sadece \%18'i sıtma riskinin yüksek olduğunu fark etmiştir. Yolcuların çoğunun, sivrisinek 1sırıklarına karşı kişisel korunma önlemlerini bildiği, ancak yalnızca \%21,4'ünün sivrisinek kovucuları ve \%12,1'inin böcek öldürücüleri taşıdığ ${ }_{1}$ belirlenmiştir taşıdı ğı belirlenmiştir.

Aro ve diğerleri (2009) çalışmasında genç turistlerin yaşlılara göre ve tatil amaçlı seyahat edenlerin iş seyahatleri gerçekleştirenlere göre daha fazla sağlık riski almaya istekli olduklarını belirlemiştir. Farklı turist türleri seyahatleri sırasında farklı riskler algılayabilmektedir. Günümüzde küresel seyahat ve salgın tehdidi sırasında, insanların sağlık risk algıları ve davranışları hakkında bilgi edinmeye acil ihtiyaç olduğu belirtilmiştir.

Richter (2003), son zamanlarda üç düzineden fazla insanın tropikal ülkelerden kaynaklanan hastalıklara yakalandığını belirtmiştir. Ayrıca Pearce (1981), tropik adaları ziyaret ederken turistlerin \%30'unun soğuk algınlığı, mide bulantısı, mide rahatsızlığı ve ishal için tıbbi yardım alması gerektiğini bulmuştur. Maser ve Weiermair (1998) seyahatle ilgili riskleri, doğal afetler, hijyen ve hastalıklar, suç ve kazalar dahil olmak üzere çeşitli kategorilere ayırmıştır.

Rittichainuwat ve Chakraborty (2009), SARS ve kuş gribinin uluslararası seyahatlere çıkma kararları üzerindeki etkilerini belirlemeye yönelik bir çalışma gerçekleştirmiştir. Çalışmanın sonucunda katılımcıların büyük çoğunluğunun bu hastalıkların uluslararası seyahatlere çıkmalarını engellediğini belirtmiştir. Gelen bazı turistlerin bu hastalıklar hakkında çok az bilgi sahibi olması çalışmanın diğer sonucudur. Katılımcıların yarısından fazlası, seyahat masrafları daha düşük olsa kişisel güvenliğini göz ardı etmeyeceklerini belirtmiştir. Terörizm tehlikesi varsa katılımcıların yaklaşık \%38'i tamamen seyahat etmeyi bırakacağını belirtmiştir. Yarısından fazlası ise, terör tehdidi sırasında seyahat etmekten ziyade daha az tehlikeli bir varış yerine seyahat etmeyi seçeceğini söylemiştir. Gelişmekte olan ülkelere yaz aylarında yapılan seferlere katılan 644 İngiltere genci arasındaki hastalık ve yaralanma sıklığını araştıran bir araştırma, tıbbi tavsiye almak isteyenlerin çoğunluğunun en sık şikâyetinin gastrointestinal semptomlar, baş ağrısı ve solunum belirtileri olduğunu ortaya koymuştur. Gelişmekte olan bir ülkeye seyahat eden 2,402 İngiltere genci üzerinde yapılan daha sonraki bir çalışmada en sık karşılaşılan sorunların gastrointestinal, soğuk veya boğaz ağrısı, baş ağrısı olduğunu göstermiştir. Afrika'ya seyahat eden öğrencilerde onaylanmış altı sıtma vakası olduğu tespit edilmiştir. Yurtdışında okuyan 1197 Çinli öğrencilere yönelik gerçekleştirilen çalışmada, katılımcıların \%75'i seyahat öncesi sağlık danışmanlığı talep etmemiş ve \%48'i seyahat sağlığı önlemi almamıştır. Tavsiye alanların \%41'i uzman olmayan kaynaklardan aldığını belirtmiştir (Aktaran: Hartjes vd., 2009). Heywood ve diğerleri (2012), seyahat eden öğrencilerin seyahat öncesi sağlık tavsiyelerine katılımlarının düşük olduğunu belirlemiştir. Katılımcıların sadece $\% 32,4^{\prime}$ ü son seyahatlerinden önce sağlık uzmanından koruyucu sağlık önerileri aradıklarını bildirmiştir.

Jonas ve diğerleri (2011) tarafından yapılan çalışmada risk algısı türlerinden en yüksek algılanan riskin suç ve daha sonra sağlık konusu olduğu ortaya çıkmıştır. Algılanan sağlık riskleri üç farklı gruba ayrılmıştır: Birincisi, çevresel olarak tetiklenen faktörlerdir. Bunlar arasında su kalitesi, algılanan risk seviyesi en yüksek ortalamaya sahip faktör olmuştur. Diğerleri ise sağlık hizmeti kalite sistemleri, gıda güvenliği ve son olarak hastalık enfeksiyonudur. İkinci grup, yarı kontrollü risk faktörlerini belirtmektedir ve hepsi orta seviye algılanan sağlık risk faktörleri olarak fiziksel yaralanma, tesislerinin güvenliği ve çevresel-fiziksel koşulları içermektedir. Üçüncü grup, turistler tarafından tamamen kontrol edilebilen cinsel hastalıklar ve uyuşturucu bağımlılığı gibi 
sağlık risklerine dayanmaktadır. Turistler tarafından kontrol edilmesi en kolay olan riskler olduğu için cinsel yolla bulaşan hastalıklar ve ilaç sorunları en düşük algılanan risk seviyesine sahiptir. Gıda güvenliği konusunda akraba arkadaş ziyareti amacıyla gidenlerin daha az endişe duydukları, fakat dini koşulları yerine getirmek isteyen turistlerin çok daha endişeli olduğu belirlenmiştir. Barton (1994) gezginleri etkileyebilecek 12 olası afet türünü sınıflandırmıştır. Bu türlerin üçü doğal ortamlar, bakteri enfeksiyonu ve terörist ya da savaşla ilgili faaliyetlerdir. Chen ve Gürsoy (2001) varış yerinin emniyetini ve temizliğini seyahat varış yerlerinin seçiminde en önemli iki faktör olarak tanımlamıştır. Baloğlu ve Uysal (1996), algilanan hijyen ve kişisel güvenlik standardını, varış noktasına seyahat için iki önemli çekme faktörü olarak belirlemiştir. Sirakaya ve diğerleri (1996), 279 öğrenci algısına dayanarak, seyahat destinasyon seçeneklerini etkileyen dışsal faktörlerin politik ve sosyal ortamlar, salgın hastalıklar, doğal afetler ve terörizm olduğunu tespit etmiştir.

Sağlık davranışı teorileri, algılanan yüksek zarar riskinin insanları risklerini azaltmak için harekete geçmeye teşvik etmesi gerektiği konusunda hem fikirdir (Brewer vd., 2004). Chien ve diğerleri (2017) çalışmasında algılanan risk ile endişe arasındaki ilişkiyi ve bu iki yapının davranışı nasıl etkilediğini araştırmıştır. Bireylerin endişe düzeylerinin seyahat sağlığı risk algılarını belirlemede önemli rol oynadığını ortaya koymuştur. Çalışmada bireylerin kaygı düzeyi arttıkça algılanan seyahat riskinin de arttığı sonucuna ulaşılmıştır. Sonuçlar endişe durumunun artan sağlık riski algıları yoluyla koruyucu davranışı motive ettiğini göstermektedir. Avustralya'da yapılan bir araştırmada, yüksek risk algılandığında seyahat öncesi sağlık tavsiyesi alma oranın da arttığı belirlenmiştir (Wilder-Smith vd., 2004).

Heywood ve diğerleri (2012) çalışmasında seyahat öncesi sağlık tavsiyesi alımının genel olarak düşük olduğunu belirtmiştir. Katılımcıların yarısından fazlası son uluslararası seyahatlerinden önce sağlık uzmanından herhangi bir tavsiye almadığını bildirmiştir. Wynberg ve diğerleri (2012) katılımcıların büyük çoğunluğunun seyahat öncesi sağlık danışmanlığı istediğini ve şirket sağlık kaynağı kullandığını belirlemiştir. Yurt dışına seyahat ederken insanlar için ciddi yaralanma riskinin daha fazla olduğu düşünülmektedir. Son zamanlarda seyahat sigortası talepleri anketinde bildirilen geri dönen Avustralyalı turistlerin temel sağlık şikâyetleri arasında, solunum, kas-iskelet sistemi, gastrointestinal, kulak, burun boğaz ve diş sorunları yer almaktadır. Araştırmadan elde edilen sonuçlara yönelik olarak seyahat edenlere verilen sağlık önerileri varış yerine özgü olmall, seyahat eden kişinin sahip olabileceği herhangi bir tıbbi problemi veya alerjiyi dikkate almalı ve seyahatin niteliğine ve süresine bağlı olmalı önerileri getirilmiştir.

Seyahat sağlığı danışmanlığı seyahat edenler için seyahat öncesi hazırlığın önemli bir parçası olmasına rağmen, sağlık profesyonelleri ve seyahat endüstrisi için en büyük sorunlardan biri, seyahat etmek için nitelikli bir kaynaktan sağlık tavsiyesi almamaktır (Aziz vd., 2018). Sağlık riski söz konusu olduğunda, turistler için uygun, güvenilir ve profesyonel bilgi eksikliği mevcuttur. İskoçya'daki turist broşürlerinin \%80'inde sağlık riskleri hakkında özel bir bilgi bulunmamaktadır. Bunlardan sadece çok azında genel sağlık tavsiyeleri mevcuttur. Seyahat acentaları ayrıca sağlık riskleri söz konusu olduğunda güvenilir ve deneyimli bilgi kaynakları olarak kabul edilmemektedir. Avustralya'da, katılımcıların \%51'i seyahate çıkmadan önce seyahat acentalarından sağlık konularında güvenlik bilgisi almadıklarını belirtmiştir. İngiltere' deki seyahat acentaları arasında yapılan bir başka çalışmada ise, acentalarıyla birlikte Hindistan veya Kenya'ya organize bir tura çlkmış olan yolcuların \%61'ine her iki ülkede de bilinen yüksek sağlık riski olmasına rağmen herhangi bir sağlık bilgisi ve önerisi verilmediği görülmüştür (Jonas vd., 2011). Wilder-Smith ve diğerleri (2004) tarafından yapılan çalışmada, katılımcılar ülkede aşı ile önlenebilir bulaşıcı hastalık ve sıtma riskini düşük olarak algılamıştır. Genel olarak, seyahat edenlerin \%5'inden azı seyahate hazırlanırken aşılanmıştır. En sık seyahat aşılaması hepatit A ve B olduğu belirlenmiştir. Sıtmanın olduğu endemik bölgelere seyahat 
edenlerin sadece \%40'ı yanında sıtma önleyici ilaç taşımıştır. Batılı turistler ile karşılaştırıldığında, Asya uyruklu olanların, önleyici danışmanlık ve aşılama konusunda daha az farkındalığı olduğu belirlenmiştir.

\section{YÖNTEM}

Yabancı turistlerin tatillerinden bekledikleri faydaları, Türkiye hakkındaki sağlık risk algılarını ve önleme davranışlarını belirlemek bu çalışmanın amacını oluşturmaktadır. Belirlenen amaçlar doğrultusunda araştırmanın örneklemini yabancı turistler oluşturmaktadır. Araştırma, turist giriş giriş çıkışlarının en fazla olduğu İstanbul, İzmir ve Antalya havaalanlarında uygulanmıştır. Veri toplama aracı olarak anket tercih edilmiştir. Araştırmada kullanılan anket dört bölümden oluşmaktadır. İlk bölümde turistlerin sosyo-demografik ve seyahat özelliklerini tespit etmeye yönelik sorular bulunmaktadır. Anketin ikinci bölümünde turistlerin tatillerinden bekledikleri faydaları belirlemek için konu ile ilgili çalışmalar (Haley, 1968; Palacio ve McCool, 1997; Botschen, Thelen ve Pieters, 1999; Chen, 2000; Yannopoulos ve Rotenberg 2000; Hong ve Koh, 2002; Jang, Morrison ve Oleary, 2002; Frochot, 2005; Molera ve Albaladejo, 2007; Birdir, 2009; Park vd., 2011; Kuo, Akbaria ve Subroto, 2012; Arunachalam ve Kumar, 2018) incelenmiştir. İncelemeler doğrultusunda daha önce turizm sektöründe turistlerin yaz tatillerinden bekledikleri faydaları belirlemek için kullanılan Birdir'in (2009) çalışmasından yararlanılmıştır. Birdir'in çalışmasında kullandığı madde sayısı 40 iken bu çalışma için kumar maddesi çıkarılmış ve 39 maddeyle çalışmaya başlanmıştır. Araştırmada kullanılan maddeler Türkçe dilinden İngilizce, Almanca ve Rusçaya uzmanlar tarafından çevrilmiştir. Katılımcıların tatillerinden bekledikleri fayda soruları için 1: Hiç Önemli Değil 2: Önemli Değil 3: Ne Önemli Ne Önemsiz 4: Önemli 5: Çok Önemli aralığında 5'li Likert derecelendirme kullanılmıştır. Anketin üçüncü bölümünde katılımcıların sağlık risk algılarını belirlemeye yönelik çeşitli sorular sorulmuştur. Soruların belirlenmesinde Lepp ve Gibson, 2003; Hamer ve Connor, 2004; Hartjes vd., 2009; Aro vd., 2009; Rittichainuwat, Chakraborty, 2009; Zhang vd., 2011; Zimmermann vd., 2013; Balaban vd., 2014; Aziz vd., 2018 çalışmalarından yararlanılmıştır. Anketin son bölümünde ise katılımcıların sağlık ve sağlık dışı riskleri önleme davranışlarını tespit etmek için belirlenen sorular sorulmuştur. Soruların belirlenmesinde Mitchell ve Vassos, 1998; Mitchell vd., 1999; Law, 2006; Fuchs ve Reichel, 2011; Çetinsöz ve Ege, 2012; Adam, 2015 çalışmalarından yararlanılmıştır. Katılımcıların Türkiye hakkında algıladıkları sağlık riski nedir sorusu için 1 ve 10 (1 en az riskli-10 en çok riskli) arasında derecelendirme kullanılmıştır.

Anketin pilot uygulaması 2019 Nisan-Haziran aylarında İstanbul, İzmir, Antalya havaalanlarında gerçekleştirilmiştir. Toplam 100 anket elde edilmiş ve veriler istatistik programına yüklenmiştir. Tatilden bekledikleri faydaları belirlemeye yönelik ölçeğin Cronbach's Alfa değeri 0,83 olarak belirlenmiştir.

Katılımcıların demografik ve seyahat özelliklerini ortaya koymak amacıyla elde edilen veriler, katılımcıların tatillerinden bekledikleri faydaları gösteren veriler, katılımcıların sağlık risk algısı ile önleme davranışları ile ilgili veriler frekans ve yüzde dağılımları verilerek değerlendirilmiştir. Ardından ölçeğin güvenilirlik analizleri (Cronbach Alpha) tamamlanarak, ölçekle ilgili ifadelerin aritmetik ortalama ve standart sapma değerlerine ulaşılmıştır. Fayda ölçeğine öncelikle faktör analizi yapılmış ve 6 faktör belirlenmiştir. Belirlenen 6 faktöre kümeleme analizi (Two Step Cluster) yapılmış ve dört küme belirlenmiştir. Kümelerin doğru sınıflandırıldığını görmek için ayırma analizi yapılmıştır. Elde edilen dört kümedeki katılımcıların demografik ve seyahat özelliklerine göre Ki Kare analizi yapılmıştır. Fayda faktörlerinin turistlerin demografik özelliklerine göre karşılaştırılması için Man Whitney U testi uygulanmıştır. 


\section{BULGULAR}

Bu bölümde araştırmaya katılan turistlerin demografik ve seyahat özelliklerini ortaya koymak amaçlanmıştır. Bu doğrultuda katılımcıların cinsiyetleri, medeni durumları, yaşları, eğitim durumları, gelir düzeyleri ve milliyetleri ile ilgili sorular sorulmuştur. Katılımcıların demografik özelliklerine ilişkin bulgular Tablo 1'de görülmektedir.

Tablo 1. Turistlerin Demografik Özellikleri

\begin{tabular}{|c|c|c|c|c|c|}
\hline \multicolumn{6}{|c|}{ Yabancı Turistlerin Demografik Özellikleri } \\
\hline \multirow{2}{*}{ Cinsiyet } & f & $\%$ & \multirow[b]{2}{*}{ Milliyetiniz } & $\mathrm{f}$ & \multirow[t]{2}{*}{$\%$} \\
\hline & & & & & \\
\hline Kadın & 499 & 58,6 & Rusya & 262 & 30,8 \\
\hline Erkek & 352 & 41,4 & Almanya & 109 & 12,8 \\
\hline Toplam & 851 & 100 & İngiltere & 42 & 4,9 \\
\hline Yaşınız & & & Ukrayna & 30 & 3,5 \\
\hline $16-24$ & 52 & 6,1 & Arnavutluk & 27 & 3,2 \\
\hline $25-34$ & 375 & 44,1 & Kosova & 26 & 3,1 \\
\hline $35-44$ & 296 & 34,8 & Gürcistan & 26 & 3,1 \\
\hline $45-54$ & 74 & 8,7 & Afrika & 25 & 2,9 \\
\hline $55-64$ & 23 & 2,7 & Fas & 24 & 2,8 \\
\hline 65 yaş ve üzeri & 31 & 3,6 & İ̀n & 22 & 2,6 \\
\hline Toplam & 851 & 100 & Japonya & 22 & 2,6 \\
\hline Medeni Durumunuz & & & İsveç & 22 & 2,6 \\
\hline Evli & 340 & 40,0 & İtalya & 22 & 2,6 \\
\hline Bekar & 504 & 59,2 & Suudi Arabistan & 20 & 2,4 \\
\hline Diğer & 7 & 0,8 & Irak & 19 & 2,2 \\
\hline Toplam & 851 & 100 & Pakistan & 18 & 2,1 \\
\hline Eğitim Durumunuz & & & Fransa & 15 & 1,8 \\
\hline İlkokul-Ortaokul & 36 & 4,2 & Kazakistan & 13 & 1,5 \\
\hline Lise & 46 & 5,4 & Misir & 10 & 1,2 \\
\hline Ön lisans & 218 & 25,6 & Katar & 10 & 1,2 \\
\hline Lisans & 503 & 59,1 & Hollanda & 9 & 1,1 \\
\hline Yüksek lisans- Doktora & 48 & 5,6 & Belçika & 8 & 0,9 \\
\hline Toplam & 851 & 100 & İ̀rlanda & 7 & 0,8 \\
\hline Ortalama Aylık Geliriniz & & & Norveç & 6 & 0,7 \\
\hline Düşük & 182 & 21,4 & İsrail & 6 & 0,7 \\
\hline Orta & 519 & 61,0 & İspanya & 6 & 0,7 \\
\hline Yüksek & 150 & 17,6 & Çin & 5 & 0,6 \\
\hline Toplam & 851 & 100 & İsviçre & 5 & 0,6 \\
\hline & & & Azerbaycan & 0,9 & 1,1 \\
\hline & & & Diğer & 26 & 3,1 \\
\hline & & & Toplam & 851 & 100 \\
\hline
\end{tabular}

Araştırmaya katılan turistlerin \%58,6'sı kadın, \%41,4'ü erkektir. Katılımcıların yaşları incelendiğinde \%44,1'inin 25-34 yaş aralığında olduğu belirlenmiştir. Araştırmaya katılan turistlerin \%59,2'sinin bekâr, \%40'ının evli olduğu tespit edilmiştir. Katılımcıların \%59,1'i lisans mezunudur. Ortalama gelir seviyeniz nedir sorusuna turistlerin \%61'i orta cevabını vermiştir. Milliyetleri incelendiğinde \%30,8'inin Ruslardan ve \%12,8'inin Almanlardan oluştuğu belirlenmiştir. Diğer seçeneğini işaretleyen turistlerin milliyetlerinin Tunus, Kuveyt, Ermenistan, Kırgızistan, Kore, Moldova, Filipinler, Kıbrıs, Cezayir, Özbekistan, Libya olduğu belirlenmiştir. 
Yabancı turistlerin \%81,8'i Türkiye'ye ilk kez gelmiştir. Tatilinizi nasıl planlarsınız sorusuna turistlerin \%96,7'si kendim planlarım şeklinde cevap vermiştir. Katılımcıların \%61,6'sı tatillerini bir haftadan az yaptıklarını belirtmişlerdir. Katılımcıların \%62,5'i tatilini yalnız geçireceğini belirtmiştir. Tatil için ayırdıkları ücret incelendiğinde \%28,5' inin 501-1500 Euro ve Dolar arasında bütçe ayırdıkları belirlenmiştir. Ne kadar sürede tatile çıkıyorsunuz sorusuna katılımcıların \%92,1'i yılda bir kez şeklinde cevap vermiştir. Araştırmaya katılan turistlerin \%59,3'ü tatillerini Akdeniz bölgesinde geçirdiklerini belirtmişlerdir. Katılımcıların $\% 96,9^{\prime}$ u Türkiye' de geçirdikleri son tatillerinden memnun olduklarını ifade etmişlerdir. Türkiye'ye tekrar gelmek istiyor musunuz sorusuna turistlerin \%94,6's1 evet şeklinde cevap vermiştir. Araştırmaya katılan turistlerin \%95,5'i ulaşım aracı olarak hava yolunu tercih ettiklerini belirtmişlerdir. Turistlere konaklama tercihleri sorulduğunda ise turistlerin $\% 81,8$ 'i otel/tatil köyü seçeneğini işaretlemiştir. Katılımcıların \%92,6'sı seyahat bilgi kaynağı olarak interneti \%34,2'si de arkadaş aile tavsiyesini seçmiştir. Araştırmaya katılan turistlerin \%96,3'ü seyahat amacınız nedir sorusuna dinlenme eğlenme cevabını vermiştir. Katılımcıların \%74'ü alışveriş amacıyla tatile çıktıklarını belirtmiştir. Araştırmaya katılan turistlerin \%80,8'i uluslararası gezilerini yılda bir kere yaptıklarını belirtmiştir. Turistlerin \%79,6'sı uluslararası gezilerini bir haftadan az yaptıklarını belirtmiştir. Hangi ülkeleri/bölgeleri tercih ediyorsunuz sorusuna turistlerin \%98,2'si Türkiye, \%29,6's1 Yunanistan, \%27,1'i İtalya cevabını vermiştir. Turistlerin yurtiçi gezi sıklıkları incelendiğinde \%74'ünün yılda bir kere tatile çıktığ görülmektedir. Turistlerin yurtiçi tatil süreleri ise $\% 84,4$ oranında bir iki gün şeklindedir.

Katılımcıların \%1,9'unun kronik bir rahatsızlığı varken, \%98'inin kronik bir rahatsızlığı yoktur. Araştırmaya katılan turistlerin \%88,8'i seyahatleri sırasında herhangi bir sağlık sorunuyla karşılaşmamıştır. Katılımcıların \%11,1'i ise sağlık sorunuyla karşılaştıklarını belirtmiştir. Turistlerin $\% 6,4^{\prime}$ ü seyahatleri boyunca sindirim sistemi, \%5,8'i güneş yanıkları, \%,1,4'ü ise soğuk algınlığı sorunları ile karşılaşmışlardır.

Türkiye hakkında algılanan sağlık riski sorusuna turistlerin \%81,9'u 1 puan verirken, \%,0,6's1 6 puan vermiştir. Araştırmaya katılan turistlerin $\% 98,6$ 'sı Türkiye'yi sağlık riski açısından güvenli bulduklarını belirtmişlerdir. Turistlerden Türkiye'deki trafik kaza riskini derecelendirmeleri istendiğinde $\% 23,4^{\prime} \ddot{u} 3$ puan vermiştir. Türkiye'de fiziksel yaralanma riski, su güvenliği, enfeksiyon kapma riski, cinsel yolla bulaşan hastalıklara yakalanma riski, bulaşıcı hastalıklara yakalanma riski sorularına katılımcılar 1 puan vermiştir. Gıda güvenliği sorusuna ise katılımciların 49,7'si 2 puan vermiştir.

Katılımcların tatil öncesi sağlıkla ilgili aldıkları önlemler incelendiğinde $\% 95,8$ 'inin Türkiye'ye gelmeden önce herhangi bir sağlık tavsiyesi almadığı belirlenmiştir. Sağlık tavsiyesi alanların oranı \%4,2'dir. Sağlık tavsiyesini kimlerden aldınız sorusuna katılımcıların \%1,5'i seyahat acentaları ve aile, \%1,2'si arkadaş seçeneğini işaretlemiştir. Türkiye'ye gelen turistlerin $\% 98^{\prime} \mathrm{i}$ seyahat öncesinde aşı olmamıştır. Turistlerin \%83,2'si yanında ilaç taşımamaktadır. Araştırmaya katılan turistlerin \%4,9'u seyahat sağlık sigortası aldıklarını belirtmişlerdir. Turistlerin \%95,1'i ise sağlık sigortası satın almamıştır. Seyahate çıkmadan önce alınan önlemler incelendiğinde turistlerin \%2,94'ünün ilaç taşıma, \%2,35'inin aşı, \%9,52'sinin diğer seçeneğini işaretledikleri belirlenmiştir. Diğer seçeneği işaretleyenler doktor kontrolü, diş kontrolü, kan grubu kartı, alerjilerinin olduğu ilaç listesi, kıyafet, kullanmak zorunda olunan ilaçlar, cinsel sağlık için gerekli ürünler ve kişisel bakım ürünleri cevaplarını vermişlerdir.

Turistlerin sağlık dışı aldıkları önlemler incelendiğinde; Türkiye hakkında tatil kararı ile ilgili olarak aile ve arkadaşlara danışma ifadesinin en yüksek orana sahip olduğu $(\% 78,1)$ belirlenmiştir. İkinci sırada gelen ifade ise $(\% 71,9)$ Türkiye popüler bir çekim merkezi olduğu için tercih etme cevabıdır. Daha önce Türkiye' de tanıdığınız otel ve çekim yerlerini bu tatil sürecine dahil etme $(\% 69,9)$ en çok verilen üçüncü cevap olmuştur. 
Tablo 2. Yabancı Turistlerin Tatillerinden Bekledikleri Faydalara Yönelik Bulgular

\begin{tabular}{|c|c|c|c|}
\hline Fayda Değişkenleri & Ortalama & Standart Sapma & $\begin{array}{c}\text { Göreceli Önem } \\
\text { Düzeyi } \\
\end{array}$ \\
\hline İklim Hava & 4,69 & 0,550 & 1 \\
\hline Yüzme & 4,69 & 0,610 & 2 \\
\hline Çevre & 4,68 & 0,552 & 3 \\
\hline Doğal Güzellikler & 4,64 & 0,556 & 4 \\
\hline Deniz & 4,60 & 0,618 & 5 \\
\hline Güneşlenme & 4,55 & 0,644 & 6 \\
\hline Tarihi ve Arkeolojik Yapıları & 4,29 & 0,844 & 7 \\
\hline Su Sporu Olanakları & 4,27 & 1,067 & 8 \\
\hline Mağara Gezme & 3,78 & 1,034 & 9 \\
\hline Dini Yerler & 3,75 & 0,804 & 10 \\
\hline Müzeler ve Sanat Galerileri & 3,73 & 0,770 & 11 \\
\hline Kültürel Gösteriler & 3,71 & 0,777 & 12 \\
\hline Milli Parklar & 3,67 & 0,737 & 13 \\
\hline Ulaşım & 3,65 & 0,790 & 14 \\
\hline Yerel Halkın Sıcakkanlılı̆̆ı, Yakınlığı & 3,61 & 0,762 & 15 \\
\hline Turist Danışma Merkezi & 3,55 & 0,839 & 16 \\
\hline Rehberli Şehir Turları & 3,52 & 0,835 & 17 \\
\hline Yerel Bot Turları & 3,48 & 0,770 & 18 \\
\hline Konaklanılan Yerin Rahatlığg & 3,46 & 0,883 & 19 \\
\hline Aile Ziyareti & 3,44 & 0,986 & 20 \\
\hline Kuş Gözlemciliği & 3,43 & 0,976 & 21 \\
\hline Konaklanılan Yerin Restoran Hizmeti & 3,39 & 0,894 & 22 \\
\hline $\begin{array}{l}\text { Konaklanılan Yerin Dışındaki Restoran } \\
\text { Hizmeti }\end{array}$ & 3,34 & 0,881 & 23 \\
\hline Düşük Suç Oranı & 3,33 & 0,958 & 24 \\
\hline Alışveriş Olanakları & 3,32 & 0,915 & 25 \\
\hline Sağlik Servisi & 3,30 & 0,912 & 26 \\
\hline Kamp Aktiviteleri & 3,28 & 1,003 & 27 \\
\hline Paranın Değeri-Döviz & 3,27 & 0,939 & 28 \\
\hline Konaklanılan Yerin Aile İçin Uygunluğu & 3,25 & 0,901 & 29 \\
\hline Tatil Bölgesinde Fiyatların Uygun Olması & 3,24 & 0,939 & 30 \\
\hline Destinasyonun Güvenliği & 3,03 & 1,013 & 31 \\
\hline Müzik Konserleri ve Tiyatrolar & 2,75 & 0,823 & 32 \\
\hline Gece Hayatı ve Eğlence Olanakları & 2,72 & 0,907 & 33 \\
\hline Lunapark ve Temalı Parklar & 2,56 & 0,832 & 34 \\
\hline Çevresel Ekolojik Geziler & 2,51 & 0,815 & 35 \\
\hline Korku ve Heyecan Arama & 2,48 & 0,803 & 36 \\
\hline Avcılık & 2,34 & 0,791 & 37 \\
\hline Golf & 2,34 & 0,816 & 38 \\
\hline Tenis & 2,33 & 0,813 & 39 \\
\hline
\end{tabular}

Tablo 2'de yabancı turistlerin tatillerinden bekledikleri faydalara yönelik bulgular yer almaktadır. İlk sırada "iklim-hava $(4,69)$ " ve "yüzme $(4,69)$ " en önemli tatil faydaları olarak belirlenmiştir. Yabancı turistlerin verdikleri cevaplara göre sırasıyla "çevre $(4,68)$ ”, "doğal güzellikler $(4,64)$ ", “deniz $(4,60)$ ", "güneşlenme $(4,55)$ ” ve "tarihi yerler $(4,29)$ " önemli tatil faydalarını oluşturmaktadır. 
Yabancı turistlerin vermiş oldukları cevaplara göre en az önem düzeyine sahip tatil faydaları "tenis $(2,33)$ ", "golf ve avcilik $(2,34)$ ", "korku ve heyecan $(2,48)$ ", "ekolojik geziler $(2,51)$ ", "lunapark $(2,56)$ " şeklinde belirlenmiştir.

Tablo 3. Yabancı Turistlerin Yaz Tatilinden Bekledikleri Faydalara Göre Yapılan Faktör Analizi Sonuçları

\begin{tabular}{|c|c|c|c|c|c|}
\hline & $\begin{array}{c}\text { Faktör } \\
\text { Yükü }\end{array}$ & $\begin{array}{c}\text { Öz } \\
\text { Değeri }\end{array}$ & $\begin{array}{l}\text { Açıklanan } \\
\text { Varyans }\end{array}$ & Ortalama & $\begin{array}{l}\text { Güvenilirlik } \\
\text { Katsayısı }\end{array}$ \\
\hline \multicolumn{2}{|l|}{ Ekonomiklik ve Güvenlik Faydaları } & \multirow[t]{10}{*}{7.299} & \multirow{10}{*}{19.558} & \multirow[t]{10}{*}{3.2918} & \multirow[t]{10}{*}{0.927} \\
\hline 20 & 0.823 & & & & \\
\hline 21 & 0.821 & & & & \\
\hline 22 & 0.803 & & & & \\
\hline 19 & 0.797 & & & & \\
\hline 17 & 0.778 & & & & \\
\hline 16 & 0.758 & & & & \\
\hline 18 & 0.745 & & & & \\
\hline 15 & 0.702 & & & & \\
\hline 23 & 0.697 & & & & \\
\hline \multicolumn{2}{|l|}{ Eğlence Faydaları } & \multirow[t]{6}{*}{4.212} & \multirow[t]{6}{*}{9.386} & \multirow[t]{6}{*}{2.6021} & \multirow[t]{6}{*}{0.848} \\
\hline 26 & 0.720 & & & & \\
\hline 25 & 0.690 & & & & \\
\hline 24 & 0.667 & & & & \\
\hline 27 & 0.649 & & & & \\
\hline 28 & 0.577 & & & & \\
\hline \multicolumn{2}{|l|}{ Çevre ve Deniz-Kum-Güneş Faydaları } & \multirow[t]{6}{*}{2.834} & \multirow[t]{6}{*}{9.136} & \multirow[t]{6}{*}{4.6320} & \multirow[t]{6}{*}{0.786} \\
\hline 3 & 0.769 & & & & \\
\hline 4 & 0.743 & & & & \\
\hline 2 & 0.735 & & & & \\
\hline 1 & 0.732 & & & & \\
\hline 5 & 0.673 & & & & \\
\hline \multicolumn{2}{|l|}{ Özel İlgi Faydaları } & \multirow[t]{4}{*}{1.988} & \multirow[t]{4}{*}{8.916} & \multirow[t]{4}{*}{2.3392} & \multirow[t]{4}{*}{0.833} \\
\hline 29 & 0.823 & & & & \\
\hline 31 & 0.800 & & & & \\
\hline 30 & 0.800 & & & & \\
\hline \multicolumn{2}{|l|}{ Kültürel Faydalar } & \multirow[t]{6}{*}{1.883} & \multirow[t]{6}{*}{8.820} & \multirow[t]{6}{*}{3.8289} & \multirow[t]{6}{*}{0.762} \\
\hline 9 & 0.816 & & & & \\
\hline 8 & 0.758 & & & & \\
\hline 7 & 0.694 & & & & \\
\hline 10 & 0.687 & & & & \\
\hline 6 & 0.447 & & & & \\
\hline İletişim ve Ulaşım Faydaları & & 1.406 & 7.481 & 3.5831 & 0.747 \\
\hline 13 & 0.830 & & & & \\
\hline 12 & 0.799 & & & & \\
\hline 14 & 0.705 & & & & \\
\hline 11 & 0.480 & & & & \\
\hline Toplam Güvenilirlik $\alpha=0.838$ & & & & & \\
\hline Açıklanan Toplam Varyans: \%63.296 & & & & & \\
\hline KMO örneklem yeterliliği: \%87.1 & & & & & \\
\hline Bartlett küresellik testi: $\boldsymbol{X}^{2}: 13744,989$ & $: 465, \mathrm{p}<1$ & 0001 & & & \\
\hline Genel ortalama:3.3795 & & & & & \\
\hline
\end{tabular}


Açıklayıcı faktör analizi uygulamasından önce, örneklem büyüklügünün faktör analizi yapmaya uygun olup olmadığını test etmek amacıyla Kaiser-Meyer-Olkin (KMO) testi uygulanmıştır. Kaiser Meyer Olkin (KMO) Örneklem yeterliliği oranının 0,6'nın üzerinde olması gerekir (Gürsakal, 2019: 77). KMO değeri olarak 0,5-1,0 arası değerler kabul edilebilir olarak değerlendirilirken, 0,5'in altındaki değerler faktör analizinin söz konusu veri seti için uygun olmadığının göstergesidir (Gürsakal, 2019). Analiz sonucunda KMO değerinin 0.871 olduğu belirlenmiştir. Bu sonuç doğrultusunda, örneklem yeterliliğinin faktör analizi yapmak için uygun olduğu sonucuna ulaşılmıştır. Ayrıca Bartlett Küresellik testi sonuçları incelendiğinde, elde edilen ki kare değerinin kabul edilebilir olduğu görülmüştür $\chi 2(465)=13744,989 ; p<0.0001$ ).

Araştırmada kullanılan ölçeğin faktör desenini ortaya koymak amacıyla faktörleştirme yöntemi olarak temel bileşenler analizi, döndürme olarak da dik döndürme yöntemlerinden varimax seçilmiştir. Faktör analizi ölçekteki toplam 39 maddeye uygulanmıştır. Faktör analizi yapılırken özdeğeri 1'den büyük olan faktörlerin seçilmesine ve en az .0450 düzeyinde korelasyona sahip olmasına, birden fazla faktöre yüklenen veya herhangi bir faktöre yüklenmeyen maddelerin analize dahil edilmemesine karar verilmiştir. Ölçeğin faktör desenini ortaya koymak amaciyla yapılan açıklayıcı faktör analizinde, 32., 33., 34., 35., 36., 37., 38. ve 39. maddeler herhangi bir faktör altında toplanmaması nedeniyle çıkarılmış ve kalan 31 madde 6 faktör altında toplanmıştır. Bu faktörler toplam varyansın \%63.296'sını açıklamaktadır. Çok faktörlü desenlerde, açıklanan varyansın \%50'nin üzerinde olması yeterli olarak kabul edilmektedir (Büyüköztürk, 2007; Tavşanc1l, 2005).

$\mathrm{Bu}$ çerçevede, tanımlanan bir faktörün, toplam varyansa yaptığı katkının yeterli olduğu görülmektedir. Tablo 3'de görüldügü üzere birinci faktör olan "F1: Ekonomiklik ve Güvenlik Faydaları" toplam varyansın \%19.558'ini, ikinci faktör "F2: Eğlence Faydaları" \%9.386'sını, üçüncü faktör "F3: Çevre ve Güneş-Deniz-Kum Faydaları" \%9.136'sını, dördüncü faktör "F4: Özel İlgi" \%8.916'sını, beşinci faktör "F5: Kültürel Faydalar" \%8.820'sini ve altıncı faktör "F6: İletişim ve Ulaşım Faydaları" \%7.481'ini açılamaktadır.

Araştırmada kullanılan ölçeğin ve alt boyutlarının güvenilirlikleri ayrı ayrı değerlendirildiğinde, güvenilirlik katsayıları birinci boyut için 0.927 , ikinci boyut için 0.848 , üçüncü boyut için 0.786 , dördüncü boyut için 0.833 , beşinci boyut için 0.762 , altıncı boyut için 0.747 ve ölçeğin geneli için 0.838 iyi derecede güvenilirliğe sahip olduğu tespit edilmiştir. Cronbach Alfa değerlerinin 0.60 'tan büyük olması, kullanılan ölçeklerin güvenilir olduğunu göstermektedir. Bu da çalışmada kullanılan ölçeğin içsel tutarlılıklarının iyi olduğunu göstermektedir.

Ekonomiklik ve güvenlik faydaları adı verilen ilk faktör dokuz maddeden oluşmaktadır. Bu faktör toplam varyansın \%19.558'ini açılamaktadır. Ekonomiklik ve güvenlik faydalarında bulunan maddeler faktör yüklerine göre "alışveriş olanakları (0.823)", "paranın değeri (0.821)", "tatil bölgesinde fiyatların uygun olması (0.803)", "tatil bölgesindeki düşük suç oranı (0.797)", "konaklanılan yerin dışındaki restoranların hizmeti $(0.778)$ ", "konaklanılan yerin restoran hizmeti (0.758)", "konaklama tesislerinin aile için uygunluğu (0.745)", "konaklanılan yerin rahatllğ 1 (0.702)" ve "destinasyonun güvenliği (0.697)" şeklinde sıralanmaktadır.

Eğlence faydaları olarak adlandırılan ikinci faktör beş maddeden oluşmaktadır. Bu faktör toplam varyansın \%9.386'sını açıklamaktadır. Bu faydada bulunan maddeler faktör yüklerine göre "lunaparklar ve temalı parklar (0.720)", "gece hayatı ve eğlence olanakları (0.690)", "müzik konserleri ve tiyatrolar (0.667)", "çevresel ekolojik geziler (0.649)", "korku ve heyecan arama (0.577)" olarak siralanmaktadır.

Çevre ve Deniz-Kum-Güneş faydaları olarak adlandırılan üçüncü faktör beş maddeden oluşmaktadır ve bu faktör toplam varyansın \%9.136'sını açıklamaktadır. Bu faydada bulunan 
maddeler faktör yüklerine göre "doğal güzellikler ve manzara (0.769)", "deniz plaj (0.743)", “çevre (0.735)", "iklim ve hava (0.732)", "güneşlenme (0.673)" şeklinde sıralanmaktadır.

Özel ilgi faydaları olarak adlandırılan dördüncü faktör üç maddeden oluşmaktadır. Bu faktör toplam varyansın \%8.916'sını açıklanmaktadır. Bu faydada bulunan maddeler faktör yüklerine göre "avcılık (0.823)", "golf (0.800)", "tenis (0.800)" şeklinde sıralanmaktadır.

Kültürel faydalar olarak adlandırılan beşinci faktör beş maddeden oluşmaktadır ve bu faktör toplam varyansın \%8.820'sini açıklamaktadır. Kültürel faydalarda bulunan maddeler faktör yüklerine göre "kültürel gösteriler (.816)", "müzeler ve sanat galerileri $(0.758)$ ", "dini yerler (0.694)", "milli parklar (0.687)", "tarihi ve arkeolojik yapılar (0.447)" olarak sıralanmaktadır.

İletişim ve ulaşım faydaları adı verilen altıncı faktör dört maddeden oluşmaktadır. Bu faktör toplam varyansın \%7.481'ini açıklamaktadır. Bu faydada yer alan maddeler faktör yüklerine göre "rehberli şehir turları (0.830)", "turist danışma merkezi (0.799)", "yerel halkın sıcakkanlılığ yakınlığı (0.705)", "ulaşım (0.480)" şeklinde sıralanmaktadır.

Tablo 4. Model Özeti

\begin{tabular}{|l|l|}
\hline Model Özeti & İki Aşamalı Kümeleme (Two Step) \\
\hline Algoritma & 6 \\
\hline Giriş Özellikleri & 4 \\
\hline Küme Sayı & \\
\hline
\end{tabular}

Çalışmada 6 faktöre iki aşamalı kümeleme (Two Step Cluster) algoritması uygulanmıştır. Kümeleme analizi sonucunda, altı faktöre göre dört küme olduğu belirlenmiştir. Belirlenen kümelemenin başarısı ve geçerliliği Silhouette İndeksi ile değerlendirilmiştir. Bu değerlendirmede kümelemenin başarısının yeterli kabul edilen seviyelerde olduğu görülmüştür.

Tablo 5. Kümelerin Değişken Bazlı Tanımlayıcı İstatistikleri

\begin{tabular}{|l|c|c|c|c|}
\hline & Küme 1 & Küme 2 & Küme 3 & Küme 4 \\
\hline Ekonomiklik ve Güvenlik Faydaları & 3.86 & 3.10 & 2.74 & 4.41 \\
\hline Eğlence Faydaları & 2.94 & 2.79 & 1.94 & 3.16 \\
\hline Çevre ve Güneş-Deniz-Kum Faydaları & 4.22 & 4.79 & 4.69 & 4.69 \\
\hline Özel İlgi & 2.82 & 2.81 & 1.78 & 1.47 \\
\hline Kültürel Faydalar & 3.61 & 4.05 & 3.88 & 3.33 \\
\hline İletişim ve Ulaşım Faydaları & 3.49 & 3.84 & 3.57 & 2.94 \\
\hline
\end{tabular}

Ortalamalardan yola çıkarak oluşturulmuş olan kümelere isimler verilmiştir. Birinci küme "Güneş-Deniz-Kum Faydası Arayan Turistler", ikinci küme "Kültürel Fayda Arayan Turistler", üçüncü küme "İletişim ve Ulaşım Kolaylığı İsteyen Turistler" ve dördüncü küme "Ekonomiklik, Güvenlik ve Rahatlık Arayan Turistler" olarak belirlenmiştir.

Elde edilen her kümenin, altı faktör itibariyle ortalamalarının birbirinden istatistiki olarak farklı olması beklenir. Bunu test etmek için tek yönlü varyans analizi uygulanmıştır. Uygulanan tek yönlü varyans analizi sonucuna göre, altı faktörde de kümelere göre istatistiksel olarak anlamlı bir fark olduğu görülmektedir $(\mathrm{p}<0.05)$. Wilks' Lambda testi sonucuna göre modelin ayırma fonksiyonlarının 0.000 anlamlılık düzeyi ile geçerli oldukları görülmektedir $(\mathrm{p}<0.05)$. 


\section{Fayda Faktörlerinin Turistlerin Demografik Özelliklerine Göre Karşılaştırılması}

Araştırmaya katılan katılımcıların cinsiyetlerine göre kullanılan ölçeğin boyutlarını karşılaştırmak içim Mann Whitney $U$ testi uygulanmıştır. Test sonucuna göre, katılan katılımcıların cinsiyetlerine göre Çevre ve Güneş-Deniz-Kum Faydaları boyutu puan sıra ortalamaları arasında istatistiksel olarak anlamlı bir fark olduğu belirlenmiştir $(\mathrm{p}<0.05)$. Kadın katılımcıların Çevre ve Güneş-Deniz-Kum Faydaları boyutu puan sıra ortalamasının erkek katılımcılara göre daha fazla olduğu tespit edilmiştir.

Araştırmaya katılan katılımcıların yaşlarına göre kullanılan ölçeğin boyutlarını karşılaştırmak içim Kruskal Wallis testi uygulanmıştır. Test sonucuna göre, katılan katılımcıların yaşlarına göre Ekonomiklik ve Güvenlik Faydaları, Eğlence Faydaları, Çevre ve Güneş-Deniz-Kum Faydaları, Özel İlgi ve Kültürel Faydalar boyutları puan sıra ortalamaları arasında istatistiksel olarak anlamlı bir fark olduğu belirlenmiştir ( $\mathrm{p}<0.05)$. 16-24 yaş aralığındaki katılımcıların Ekonomiklik ve Güvenlik Faydaları boyutu puan sıra ortalamasının 45-54 yaş aralığındaki katılımcılara göre daha fazla olduğu görülmektedir. 25-34 yaş aralığındaki katılımcıların Eğlence Faydaları boyutu puan sıra ortalamasının 45-54 yaş aralığındaki katılımcılara göre daha fazla olduğu belirlenmiştir.

16-24, 25-34 ve 35-44 yaş aralığındaki katılımcıların Çevre ve Güneş-Deniz-Kum Faydaları boyutu puan sıra ortalamasının 55-64 yaş aralığındaki katılımcılara göre daha fazla; 55-64 yaş aralığındaki katılımcıların Özel İlgi Faydaları boyutu puan sıra ortalamasının 16-24 ve 45-54 yaş aralığındaki katılımcılara göre daha fazla; 35-44 yaş aralığındaki katılımcıların Kültürel Faydalar boyutu puan sıra ortalamasının 16-24 ve 55-64 yaş aralığındaki katılımcilara göre daha fazla olduğu belirlenmiştir.

Katılımcların medeni durumlarına göre Çevre ve Güneş-Deniz-Kum Faydaları boyutu puan sıra ortalamaları arasında istatistiksel olarak anlamlı bir fark olduğu tespit edilmiştir $(\mathrm{p}<0.05)$. Bekar katılımcıların Çevre ve Güneş-Deniz-Kum Faydaları boyutu puan sıra ortalamasının evli katılımcılara göre daha fazla olduğu yapılan araştırmada ortaya çıkmıştır.

Lise mezunu katılımcıların Ekonomiklik ve Güvenlik Faydaları boyutu puan sıra ortalamasının ilkokul ve ortaokul mezunu katılımclara göre daha fazla; lise mezunu katılımcıların Eğlence Faydaları boyutu puan sıra ortalamasının önlisans mezunu katılımcılara göre daha fazla; ilkokul ve ortaokul mezunu katılımcıların İletişim ve Ulaşım Faydaları boyutu puan sıra ortalamasının lise, yüksek lisans ve doktora mezunu katılımcılara göre daha fazla olduğu belirlenmiştir.

Avrupa'dan gelen katılımcıların Eğlence Faydaları boyutu puan sıra ortalamasının Afrika'dan gelen katılımcılara göre daha fazla; Avrupa' dan gelen katılımcıların Çevre ve Güneş-Deniz-Kum Faydaları boyutu puan sıra ortalamasının Doğu Asya ve Pasifik'ten gelen katılımcılara göre daha fazla; Avrupa'dan gelen katılımciların Kültürel Faydalar boyutu puan sıra ortalamasının Orta Doğu'dan gelen ve Doğu Asya ve Pasifik'ten gelen katılımclara göre daha fazla olduğu belirlenmiştir.

\section{Türkiye'ye Gelen Yabancı Turistlerin Pazar Bölümlerine Göre Sağlık Risk Derecelerinin ve Aldıkları Önlemlerin Karşılaştırılması}

Her dört kümenin Türkiye'yi sağlık riski açısından güvenli buldukları belirlenmiştir. En yüksek oran \%100 ile iletişim ve ulaşım kolaylığı isteyen turistler kümesine aittir.

Ekonomiklik, Güvenlik ve Rahatlık Arayan Turistlerin Türkiye'de yaptıkları tatilde seyahat ettikleri bölge hakkında algıladıkları sağlık riski derecelerinin sıra ortalamasının, Güneş-Deniz- 
Kum Faydası Arayan Turistler, Kültürel Fayda Arayan Turistler ve İletişim ve Ulaşım Kolaylığ İsteyen Turistlerden büyük olduğu belirlenmiştir.

Kümelerin Türkiye'de gittikleri bölgede seyahate çıkmadan önce sağlık riski dışındaki aldıkları önlemler incelendiğinde Güneş-Deniz-Kum Faydası Arayan Turistler kümesinin en fazla $(77,6)$ "Tatil kararı ile ilgili olarak aile ve arkadaşlara danışma", Kültürel Fayda Arayan Turistler kümesinin en fazla $(83,8)$ "Daha önce bölgede tanıdığınız otel ve çekim yerlerini bu tatil sürecine dahil etme", İletişim ve Ulaşım Kolaylığ 1 İsteyen Turistler kümesinin en fazla $(89,7)$ "O bölgenin popüler bir çekim merkezi olması sebebiyle onu seçme / tercih etme", Ekonomiklik, Güvenlik ve Rahatlık Arayan Turistler kümesinin en fazla $(88,9)$ "Akraba ve arkadaşlardan gidilen bölge hakkında bilgi toplama" seçeneğini işaretledikleri belirlenmiştir.

Güneş-Deniz-Kum Faydası Arayan Turistler kümesi trafik kaza riskini, gıda güvenliğini, su güvenliğini, bulaşıcı hastalıklara yakalanma riskini, cinsel yolla bulaşan hastalıklara yakalanma ve fiziksel yaralanma riskini Kültürel Fayda Arayan Turistler kümesine göre daha fazla riskli bulmuştur.

Güneş-Deniz-Kum Faydası Arayan Turistlerin ve Ekonomiklik, Güvenlik ve Rahatlık Arayan Turistlerin Türkiye'de tatillerini yaptıktan sonra gittikleri bölge hakkında algıladıkları sağlık riskini derecelendirmesi Kültürel Fayda Arayan Turistler ve İletişim ve Ulaşım Kolaylığı İsteyen Turistlere göre daha fazla olduğu belirlenmiştir.

\section{SONUÇ ve ÖNERILER}

Türkiye'ye gelen yabancı turistlerin tatillerinden bekledikleri faydaların belirlenmesi ve belirlenen bu faydalara göre pazar bölümlerinin oluşturulması amacıyla yapılan bu çalışmada 851 yabancı turiste ulaşılmıştır. Araştırmaya katılan yabancı turistlerin milliyetleri incelendiğinde Rus ve Alman turistlerin ağırlıklı olduğu görülmektedir. Çalışmada yabancı turistlerin büyük çoğunluğunun Türkiye'ye ilk kez geldiği ve tatillerini kendilerinin planladıkları belirlenmiştir. Yabancı turistler yılda bir kez tatile çıktıklarını ve genellikle yalnız veya eşi ile tatillerini geçirdiklerini belirtmişlerdir. Yabancı turistlerin büyük çoğunluğu Türkiye'deki son tatilini Akdeniz Bölgesinde geçirdiğini ve tatillerinden memnun oldukların belirtmişlerdir. Yabancı turistlerin çoğunluğu Türkiye'ye tekrar gelir misiniz sorusuna evet cevabını vermiştir. Yabancı turistler ulaşım aracı olarak hava yolunu, konaklama tercihi olarak ise otel-tatil köyünü tercih etmektedirler. Yabancı turistlerin seyahat bilgi kaynakları incelendiğinde ilk sirada internetin yer aldığı ikinci sırada ise aile arkadaş tavsiyesi seçeneğinin yer aldığı görülmektedir. Dinlenme ve eğlenme Türkiye'ye gelen yabancı turistlerin seyahat amaçlarında ilk sırada yer almaktadır. Seyahat amaçları arasında alışveriş seçeneği ise ikinci sıradadır. Yabancı turistlere tatil için hangi ülkeleri tercih ediyorsunuz diye sorulduğunda ilk seçeneğin Türkiye olduğu, ikinci seçeneğin Yunanistan ve üçüncü seçeneğin ise İtalya olduğu belirlenmiştir. Yabancı turistlerin tatilleri boyunca en çok katıldıkları aktivitelerin alışveriş, güneşlenme ve eğlence olduğu görülmektedir.

Yabancı turistlerin çoğunluğunun seyahatleri sırasında herhangi bir sağlık sorunu ile karşılaşmadıkları belirlenmiştir. Karşılaşılan sağlık sorunları arasında sindirim problemleri ve güneş yanıkları yer almaktadır. Yabancı turistlerin Türkiye hakkında algıladıkları sağlık riskinin düşük düzeyde olduğu görülmektedir. Turistlerin çok büyük çoğunluğu Türkiye'yi sağlik riski açısından güvenli bir ülke olarak değerlendirmiştir.

Yabancı turistlerin seyahat öncesi aldıkları önlemler incelendiğinde çoğunluğunun sağlık tavsiyesi almadığı, aşı olmadığı ve seyahat sağlık sigortası almadığı belirlenmiş̧tir. Sağlık tavsiyesi alan turistlerin ise genellikle seyahat acentalarından ve arkadaşlarından bilgi aldıkları 
görülmektedir. Sağlık dışında alınan önlemler incelendiğinde yabancı turistlerin en fazla işaretledikleri seçenek tatil kararı ile ilgili olarak aile ve arkadaşlara danışma seçeneğidir. Çalışmanın bu sonuçları literatürdeki diğer çalışmaların sonuçlarıyla tutarlıdır. Hamer ve Connor (2004), seyahat öncesinde turistlerin çok azının sağlık tavsiyesi aldığını ve aşı yaptırdığını tespit etmiştir. Benzer şekilde Zhang ve diğerleri (2011) tarafından yapılan çalışmada katılımcıların çok azının seyahat sağlık sağlayıcılarından bilgi aldıkları belirlenmiştir. Heywood ve diğerleri (2012), seyahat eden öğrencilerin seyahat öncesi sağlık tavsiyelerine katılımlarının düşük olduğunu belirlemiştir. Katılımcıların sadece \%32,4'ü son seyahatlerinden önce sağlık uzmanından koruyucu sağlık önerileri aldıklarını bildirmiştir. Heywood ve diğerleri (2012) çalışmasında seyahat öncesi sağlık tavsiyesi alımının genel olarak düşük olduğunu belirtmiştir.

Yabancı turistlerin Türkiye'deki tatillerinden bekledikleri faydaların önem düzeyleri incelendiğinde ilk sırada iklim hava ve yüzme seçeneklerinin, ikinci sırada çevre, üçüncü sırada doğal güzellikler seçeneğinin olduğu belirlenmiştir. Turistlerin tatillerinden bekledikleri fayda maddelerine yapılan faktör analizi sonucunda ekonomiklik ve güvenlik faydaları, eğlence faydaları, çevre ve deniz-güneş-kum faydaları, özel ilgi faydaları, kültürel faydalar, iletişim ve ulaşım faydaları şeklinde 6 faktör belirlenmiştir. Altı faktöre yapılan iki aşamalı kümeleme analizi sonucunda 4 küme belirlenmiştir. Kümeler deniz-güneş-kum faydası arayan turistler, kültürel fayda arayan turistler, iletişim ve ulaşım kolaylığı isteyen turistler, ekonomiklik, güvenlik ve rahatlık arayan turistler şeklinde isimlendirilmiştir. Çalışmanın bu sonucu literatürdeki birçok çalışma tarafından desteklenmektedir (Muller, 1991; Oh, Uysal ve Weaver, 1995; Lang ve Oleary, 1997; Keng ve Cheng, 1999; Birdir ve Akdoğan, 2010; Li, Meng, Uysal ve Mihalik, 2013). Muller'ın (1991) yürüttügü çalışmada elde edilen kümelerden birisi olan güvenlik ve güvence arayanlar, çalışmadaki ekonomiklik, güvenlik ve rahatlık arayan turistler kümesiyle benzerlik taşımaktadır. Oh, Uysal ve Weaver (1995) çalışmasında güvenlik konfor arayanlar, kültür tarih arayanlar şeklinde iki küme grubu belirlemiştir. Çalışmanın sonucunda elde edilen kültürel fayda arayan turistler, ekonomiklik, güvenlik ve rahatlık arayan turistler kümeleriyle benzerlik göstermektedir. Lang ve Oleary (1997) tarafından yürütülen çalışmada kültür ve eğlence arayanlar şeklinde küme grubu belirlenmiştir. Çalışmanın sonucunda elde edilen kültürel fayda arayan turistler kümesiyle benzerlik göstermektedir. Birdir'in (2009) yürüttüğü çalışmada elde edilen kümelerden güvenlik ve konfor faydası arayanlar, deniz-güneş-kum faydaları arayanlar çalışmadaki ekonomiklik, güvenlik ve rahatlık arayan turistler ve denizgüneş-kum faydası arayan turistler kümesiyle benzerlik taşımaktadır.

Deniz-güneş-kum faydası arayan, iletişim ve ulaşım kolaylığı isteyen, ekonomiklik, güvenlik ve rahatlık arayan turistlerin çoğunluğunun evli olduğu, kültürel fayda arayan turistlerin çoğunluğunun bekâr olduğu görülmektedir. Bütün kümelerin eğitim durumlarının lisans derecesi ağırlıklı olduğu ve gelir düzeylerinin orta düzeyde olduğu belirlenmiştir.

Yapılan çalışmanın sonucunda kadın katılımcıların çevre ve güneş-deniz-kum faydaları boyutu puan sıra ortalamasının erkek katılımcılara göre daha fazla olduğu ortaya çıkmıştır. Çalışmanın bu sonucuna göre kadın katılımcıların çevre ve deniz-güneş-kum faydasına daha fazla önem verdiği söylenebilir. 16-24 yaş aralığındaki katılımcıların ekonomiklik ve güvenlik faydaları boyutu puan sıra ortalamasının 45-54 yaş aralığındaki katılımcılara göre daha fazla olduğu belirlenmiştir. Bu sonuca dayanarak yaşı genç katılımcıların ekonomiklik ve güvenlik faydasına daha fazla önem verdiği söylenebilir. Genç katılımcıların gidecekleri tatil yerlerinin ekonomik olmasını istemelerinin sebebi herhangi bir gelirlerinin olmaması veya öğrenci olmaları olabilir. Ayrıca tatil konusunda tecrübesiz oldukları için de güvenli yerleri tercih ediyor olabilirler.

25-34 yaş aralığındaki katılımcıların eğlence faydaları boyutu puan sıra ortalamasının 45-54 yaş aralığındaki katılımcılara göre daha fazla olduğu görülmektedir. Yaşı daha genç katılımcıların eğlence faydalarına daha fazla önem verdiği söylenebilir. Daha genç katılımcılar için tatillerini 
eğlenceli geçirmek diğer faydalara göre daha önemli olabilir. 55-64 yaş aralığındaki katılımcıların özel ilgi faydaları boyutu puan sıra ortalamasının 16-24 ve 45-54 yaş aralığındaki katılımclara göre daha fazla olduğu görülmektedir. Yaşı daha yüksek katılımcılar için özel ilgi faydalarının daha önemli olduğu söylenebilir. Yaşı daha yüksek katılımcılar tatilde zamanlarını eğlenerek, güneşlenerek, deniz yerine golf, tenis, avcılık gibi etkinliklere katılarak geçirmektedirler.

Bekâr katılımcıların çevre ve güneş-deniz-kum faydaları boyutu puan sıra ortalamasının evli katılımcılara göre daha fazla olduğu görülmektedir. Bekâr katılımcılar için çevre ve deniz-güneşkumun daha önemli olduğu söylenebilir. Avrupa'dan gelen katılımcıların eğlence faydaları boyutu puan sıra ortalamasının Afrika'dan gelen katılımclara göre daha fazla olduğu görülmektedir. Avrupa'dan gelen katılımcıların çevre ve deniz-güneş-kum faydaları boyutu puan sıra ortalamasının Doğu Asya ve Pasifik'ten gelen katılımcılara göre daha fazla olduğu görülmektedir. Avrupa' dan gelen katılımclların kültürel faydalar boyutu puan sıra ortalamasının Orta Doğu ile Doğu Asya ve Pasifik'ten gelen katılımcılara göre daha fazla olduğu görülmektedir. Avrupa'dan gelen katılımcılar için eğlence, çevre ve deniz-güneş-kum ve kültürel faydaların daha önemli olduğu söylenebilir.

Her dört kümedeki katılımcıların Türkiye'yi sağlık riski açısından güvenli buldukları belirlenmiştir. Yapılan analizler sonucunda ekonomiklik, güvenlik ve rahatlık arayan turistlerin Türkiye' de yaptıkları tatilde seyahat ettikleri bölge hakkında algıladıkları sağlık risk derecesinin diğer kümelere göre daha fazla olduğu tespit edilmiştir. Uslu (2017) tarafından yapılan çalışmanın sonucunda yabancı turistlerin çoğunluğunun Türkiye'yi güvenli olarak gördükleri belirlenmiştir. Ateşoğlu ve Türker (2014) tarafından yürütülen çalışmada katılımcıların Türkiye imaj algısının olumluya yakın olduğu tespit edilmiştir.

Sağlık riski dışında alınan önlemler incelendiğinde deniz-güneş-kum faydası arayan turistlerin en fazla "Tatil kararı ile ilgili olarak aile ve arkadaşlara danışma", kültürel fayda arayan turistlerin en fazla "Daha önce bölgede tanıdığınız otel ve çekim yerlerini bu tatil sürecine dahil etme", iletişim ve ulaşım kolaylığı isteyen turistlerin en fazla "O bölgenin popüler bir çekim merkezi olması sebebiyle onu seçme / tercih etme", Ekonomiklik güvenlik ve rahatlik arayan turistlerin en fazla "Akraba ve arkadaşlardan gidilen bölge hakkında bilgi toplama" seçeneğini işaretledikleri görülmektedir. Turistlerin risk önleme davranışları ile ilgili elde edilen bu sonuçlar literatürdeki diğer çalışmalar tarafından desteklenmektedir (Mitchell ve Vassos 1997; Mitchell vd., 1999; Law 2006). Fuchs ve Reicel (2011) çalışmasında, risk azaltma stratejileri arasında seyahat acentaları, arkadaşlar ve akrabalardan bilgi alınması, internet, elektronik ve yazılı medyadan bilgi toplanması, varış yerini daha önce ziyaret etmiş kişilere danışmak gibi sonuçlara ulaşmıştır.

Deniz-güneş-kum faydası arayan turistler trafik kaza riskini, gıda güvenliğini, su güvenliğini, bulaşıcı hastalıklara yakalanma riskini, cinsel yolla bulaşan hastalıklara yakalanma ve fiziksel yaralanma riskini kültürel fayda arayan turistlere göre daha fazla riskli bulmuştur. Deniz-güneşkum faydası arayan turistlerin ve ekonomiklik, güvenlik ve rahatlık arayan turistlerin Türkiye'de tatillerini yaptıktan sonra gittikleri bölge hakkında algıladıkları sağlık risk derecesi diğer kümelere göre daha fazladır.

Türkiye'ye tatil için gelen yabancı turistlerin bekledikleri faydaların iklim, hava, yüzme, deniz ve doğal güzellikler olması sebebiyle yapılacak tanıtımların bu konular ağırlık verilerek yapılması turist çekebilmek için önemli olabilir. En az önemli olan faydalar turistler tarafından tenis, golf, av şeklinde belirlenmiştir. Bunlar gibi etkinlikler için de reklam faaliyetleri ve tanıtım kampanyaları yapılarak Türkiye'deki farklı turizm türleri de ön plana çıkarılabilir. Çalışma sonucunda ortaya çıan pazar bölümleri incelendiğinde turistlerin sadece deniz-güneş-kum için Türkiye'ye gelmediği görülmektedir. Kültürel fayda arayan, iletişim ulaşım kolaylığı isteyen, 
ekonomiklik, güvenlik ve rahatlık arayan turistler için de çeşitli çalışmalar yapılarak onların tatmin düzeylerinin arttırılması turizm sektörü ve sürekliliği için önemli olabilir. Gelen turistlerin beklenti ve isteklerinin öğrenilmesi, nelerden hoşlandığı, tatilinden ne beklediğinin bilinmesi turistlerin memnuniyet düzeylerini arttırabilir ve Türkiye'nin tekrar ziyaret edilmesini sağlayabilir. Pazarlama yöneticileri ve turizm sektör çalışanları mal ve hizmet üretirken belirlenen pazar bölümlerini dikkate alarak daha fazla turist çekebilirler. Deniz-güneş-kum faydası arayan turistlere tanıtım yapılırken Türkiye'nin çeşitli doğal güzellikleri, plajları, iklimi ile ilgili bilgiler verilirken, kültürel fayda arayan turistlere Türkiye'deki çeşitli etkinlikler hakkında bilgiler verilebilir. Böylece karşıdaki turistin ne istediği bilindiği için turist daha kolay karar verebilir.

Türkiye'ye gelen yabancı turistlerin Türkiye hakkındaki sağlık risk algıları düşük düzeydedir. Türkiye hakkında böyle olumsuz düşüncelerinin olmaması tatile gitmeye karar verme aşamasında Türkiye'nin seçilmesini kolaylaştırabilir.

Özellikle pandemi sonrasında yapılacak tanıtımlarda sağlık ve hijyen vurgusunun olması turistlerin sağlık risk algılarının düşük olmasına devam etmesi için yararlı olabilir. Türkiye pandemi öncesinde olduğu gibi pandemi sonrasında da sağlık riski düşük bir ülke olarak tanınabilir. Riski daha fazla algılayan turist kümeleri için yapılan tanıtımlarda Türkiye'nin riskli bir ülke olmadığı vurgulanabilir.

Yapılacak tanıtımlarda ülkenin sağlık durumu, konaklama işletmelerinin sağlık ile ilgili aldıkları önlemler hakkında bilgilere yer verilebilir. Ayrıca turistlerin seyahat sağlık sigortası satın almaları desteklenebilir.

Pandemi sonrasında yapılacak araştırmalarda turistlerin Türkiye hakkındaki sağlık risk algıları ve önleme davranışları yeniden araştırılabilir. Ayrıca turistlerin tatillerinden bekledikleri faydaların pazar bölümlendirmesi yapılarak sağlık kavramının önemli hale gelip gelmediği belirlenebilir. Yapılacak araştırmalarda pandeminin turistlerin davranışlarını ve beklentilerini ne kadar etkilediği araştırılabilir. Yabancı turistlerin risk önleme davranışlarında herhangi bir değişiklik olup olmadığı araştırılabilir. Yabancı turistlerin bundan sonraki seyahatlerinde aşı olma, sağlık sigortası alma gibi davranışların önemli hale gelip gelmediği araştırılabilir.

\section{KAYNAKÇA}

Adam, I. (2015). Backpackers risk perceptions and risk reduction strategies in Ghana. Tourism Management, 49: 99-108.

Albayrak, T. and Caber, M. (2018). A motivation-based segmentation of holiday tourists participating in white-water rafting. Journal of Destination Marketing \& Management, 9: 64-71.

Altunışık, R. (2009). Turizm işletmelerinde pazarlamanın temelleri ve iki farklı pencereden pazarlama yönetimi: üretici ve tüketici bakış açısı. C. Avcıkurt, Ş. Demirkol ve B. Zengin (Editörler). Turizm İşletmelerinin Pazarlamasında $7 P$ ve $7 C$ içinde (s.7-47) İstanbul: Değişim Yayınları.

Aro, A. R., Vartti, A. M., Schreck, M., Turtiainen, P. and Uutela, A. (2009). Willingness to take travel-related health risks-a study among Finnish tourists in Asia during the avian influenza outbreak. International Journal of Behavioral Medicine, 16(1): 68-73.

Arunachalam, D. and Kumar, N. (2018). Benefit-based consumer segmentation and performance evaluation of clustering approaches: An evidence of data-driven decision-making. Expert Systems with Application, 111(30): 11-34. 
Ateşoğlu, İ. ve Türker, A. (2014). Tatil yeri seçiminde ülke imajının turistin risk algısı üzerine etkisi. Uluslararası Alanya İşletme Fakültesi Dergisi, 6(2): 9-28.

Aziz, M. M., El-Megeed, H. S. A. and Ellatif, M. A. M. A. (2018). Pre-travel health seeking practices of Umrah pilgrims departing from Assiut International Airport, Egypt. Travel Medicine and Infectious Disease, 23: 72-76.

Balaban, V., Warnock, E., Dhara, V. R., Jean-Louis, L. A., Sotir, M. J. and Kozarsky, P. (2014). Health risks, travel preparation, and illness among public health professionals during international travel. Travel Medicine and Infectious Disease, 12(4): 349-354.

Baloğlu, S. and Uysal, M. (1996). Market segments of push and pull motivations: A canonical correlation approach. International Journal of Contemporary Hospitality Management, 8(3): 32-38.

Barton, L. (1994). Crisis management: Preparing for and managing disasters. Cornell Hotel and Restaurant Administration Quarterly, 35(2): 59-65.

Birdir, S. S. ve Akdoğan, M. Ş. (2010). Fayda temelli bölümlendirme: Antalya örneği. Că̆g University Journal of Social Sciences, 7(1): 21-34.

Birdir, S.S. (2009). Yaz Tatilinden Beklenen Faydalara Göre Turist Pazarının Bölümlendirilmesi: Antalya'da Yapılan Bir Araştırma. Yayınlanmamış Doktora Tezi, Erciyes Üniversitesi: Kayseri.

Blattberg, R. C. and Sen, S. K. (1974). Market segmentation using models of multidimensional purchasing behavior: a new segmentation strategy designed to provide better information to the marketing decision maker. Journal of Marketing, 38(4): 17-28.

Bloom, Z. J. (2004). Tourist market segmentation with linear and nonlinear techniques. Tourism Management, 25: 723-733.

Botschen, G., Thelen, E. M. and Pieters, R. (1999). Using means-end structures for benefit segmentation: An application to services. European Journal of Marketing, 33(1/2): 38-58.

Brewer, N. T., Weinstein, N. D., Cuite, C. L. and Herrington, J. E. (2004). Risk perceptions and their relation to risk behavior. Annals of Behavioral Medicine, 27(2): 125-130.

Büyüköztürk, Ş. (2007). Sosyal Bilimler İçin Veri Analizi El Kitabı. Ankara: Pegem Yayıncılık.

Chen, J. S. (2000). Norwegians' preferences for US lodging facilities: Market segmentation approach. Journal of Travel Tourism Marketing, 9(4): 69-82.

Chen, J. S. and Gürsoy, D. (2001). An investigation of tourists' destination loyalty and preferences. International Journal of Contemporary Hospitality Management, 13(2): 79-85.

Chien, P. M., Sharifpour, M., Ritchie, B. W. and Watson, B. (2017). Travelers' health risk perceptions and protective behavior: a psychological approach. Journal of Travel Research, 56(6): 744-759.

Çetinsöz, B. C. ve Ege, Z. (2012). Turistlerin demografik özelliklerine göre risk azaltma stratejileri: Alanya örneği. Anatolia: Turizm Araştırmaları Dergisi, 23(2): 159-172.

Dayour, F., Park, S. and Kimbu, A. N. (2019). Backpackers' perceived risks towards smart phone usage and risk reduction strategies: A mixed methods study. Tourism Management, 72: 52-68.

Dickson, P. R. (1982). Person-situation: Segmentation's missing link. The Journal of Marketing, 46(4): 56-64.

Dickson, P. R. and Ginter, J. L. (1987). Market segmentation, product differentiation, and marketing strategy. The Journal of Marketing, 51(2): 1-10. 
Elrod, T. and Winer, R. S. (1982). An empirical evaluation of aggregation approaches for developing market segments. The Journal of Marketing, 46(4): 65-74.

Engel, F. J, Fiorillo, F, H. and Cayley, A. M. (1971). Market Segmentation Concepts and Applications. New York, Holt, Rinehart and Winston.

Eusébio, C., Carneiro, M. J., Kastenholz, E. and Alvelos, H. (2017). Social tourism programmes for the senior market: a benefit segmentation analysis. Journal of Tourism and Cultural Change, 15(1): 59-79.

Frochot, I. (2005). A benefit segmentation of tourists in rural areas: a Scottish perspective. Tourism Management, 26(3): 335-346.

Fuchs, G. and Reichel, A. (2011). An exploratory inquiry into destination risk perceptions and risk reduction strategies of first time vs. repeat visitors to a highly volatile destination. Tourism Management, 32(2): 266-276.

Ghazali, M. H., Shah, S. A. and Mahmood, M. I. (2018). Factor analysis of a novel scoring-based instrument on forecasting Malaysian travelers' behavioral preparedness for travel-related infectious diseases. International Journal of Travel Medicine and Global Health, 6(2): 54-63.

Gürsakal, S. (2019). Sosyal Bilimlerde SPSS Uygulamalı Çok Değişkenli İstatiksel Analiz Teknikleri. Bursa: Dora Basım Dağıtım.

Hacıoğlu, N. (2014). Turizm Pazarlaması. (9. Basım), Ankara: Nobel Yayınları.

Hajibaba, H., Gretzel, U., Leisch, F. and Dolnicar, S. (2015). Crisis-resistant tourists. Annals of Tourism Research, 53: 46-60.

Haley, R. I. (1968). Benefit segmentation: A decision-oriented research tool. The Journal of Marketing, 32(3): 30-35.

Hamer, D. H. and Connor, B. A. (2004). Travel health knowledge, attitudes and practices among United States travelers. Journal of Travel Medicine, 11(1): 23-26.

Hartjes, L. B., Baumann, L. C. and Henriques, J. B. (2009). Travel health risk perceptions and prevention behaviors of US study abroad students. Journal of Travel Medicine, 16(5): 338-343.

Heywood, A. E., Zhang, M., MacIntyre, C. R. and Seale, H. (2012). Travel risk behaviours and up take of pre-travel health preventions by university students in Australia. BMC Infectious Diseases, 12(43): 2-9.

Hong, H. and Koh, A. (2002). Benefit segmentation of the Korean female apparel market: Importance of store attributes. Clothing and Textiles Research Journal, 20(4): 205-214.

Hsu, C. H. and Kang, S. K. (2007). CHAID-based segmentation: International visitors' trip characteristics and perceptions. Journal of Travel Research, 46(2): 207-216.

Jang, S. C., Morrison, A. M. and OLeary, J. T. (2002). Benefit segmentation of Japanese pleasure travelers to the USA and Canada: selecting target markets based on the profitability and risk of individual market segments. Tourism Management, 23(4): 367-378.

Jonas, A., Mansfeld, Y., Paz, S., and Potasman, I. (2011). Determinants of health risk perception among low-risk-taking tourists traveling to developing countries. Journal of Travel Research, 50(1): 87-99.

Keng, K. A. and Cheng, J. L. L. (1999). Determining tourist role typologies: An exploratory study of Singapore vacationers. Journal of Travel Research, 37(4): 382-390. 
Kerstetter, D.L., Hou, J., and Lin, C. (2004). Profiling Taiwanese ecotourists using a behavioral approach. Tourism Management, 25(4): 491-498.

Kesic, T. and Piri-Rajh, S. (2003). Market segmentation on the basis of food-related lifestyles of Croatian families. British Food Journal, 105(3): 162-174.

Kinnear, C. T. and Bernhardt, L. K. (1990). Principles of Marketing. Third Edition.

Kotler, P., Armstrong, G., Saunders J. and Wong V. (1999), Principles of Marketing, Second European Edition.

Kuo, R. J., Akbaria, K. and Subroto, B. (2012). Application of particle swarm optimization and perceptual map to tourist market segmentation. Expert Systems with Applications, 39(10): 87268735 .

Lang, C. T. and Oleary, J. T. (1997). Motivation, participation, and preference: A multisegmentation approach of the Australian nature travel market. Journal of Travel Tourism Marketing, 6(3-4): 159-180.

Law, R. (2006). The perceived impact of risks on travel decisions. International Journal of Tourism Research, 8(4): 289-300.

Legoherel, P., Hsu, C. H. and Dauce, B. (2015). Variety-seeking: Using the CHAID segmentation approach in analyzing the international traveler market. Tourism Management, 46: 359-366.

Lepp, A. and Gibson, H. (2003). Tourist roles, perceived risk and international tourism. Annals of Tourism Research, 30(3): 606-624.

Li, X. R., Meng, F., Uysal, M. and Mihalik, B. (2013). Understanding China's long-haul outbound travel market: An overlapped segmentation approach. Journal of Business Research, 66(6): 786-793.

Maser, B. and Weiermair, K. (1998). Travel decision-making: From the vantage point of perceived risk and information preferences. Journal of Travel \& Tourism Marketing, 7(4): 107-121.

Mitchell, V. W. and Vassos, V. (1998). Perceived risk and risk reduction in holiday purchases: A cross-cultural and gender analysis. Journal of Euro Marketing, 6(3): 47-79.

Mitchell, V. W., Davies, F., Moutinho, L. and Vassos, V. (1999). Using neural networks to understand service risk in the holiday product. Journal of Business Research, 46(2): 167-180.

Molera, L. and Albaladejo, I. P. (2007). Profiling segments of tourists in rural areas of SouthEastern Spain. Tourism Management, 28(3): 757-767.

Moreira, P. (2008). Stealth risks and catastrophic risks: On risk perception and crisis recovery strategies. Journal of Travel \& Tourism Marketing, 23(2-4): 15-27.

Muller, T. E. (1991). Using personal values to define segments in an international tourism market. International Marketing Review, 8(1): 57-70.

Oh, H. C., Uysal, M. and Weaver, P. A. (1995). Product bundles and market segments based on travel motivations: A canonical correlation approach. International Journal of Hospitality Management, 14(2): 123-137.

Özel, Ç. H. (2010). Güdülere dayal yerli turist tipolojisinin belirlenmesi: iç turizm pazarına yönelik bir uygulama. Yayınlanmamış Doktora Tezi, Anadolu Üniversitesi: Eskişehir.

Palacio, V. and McCool, F. S. (1997). Identifying ecotourists in Belize through benefit segmentation: A preliminary analysis. Journal of Sustainable Tourism, 5(3): 234-243. 
Park, H., Lim, C. M., Bhardwaj, V. and Kim, Y. K. (2011). Benefit segmentation of TV home shoppers. International Journal of Retail \& Distribution Management, 39(1): 7-24.

Pearce, P. L. (1981). "Environment shock": a study of tourists' reactions to two tropical islands. Journal of Applied Social Psychology, 11(3): 268-280.

Peattie, S., Clarke, P. and Peattie, K. (2005). Risk and responsibility in tourism: promoting sunsafety. Tourism Management, 26(3): 399-408.

Qi, C. X., Gibson, H. J. and Zhang, J. J. (2009). Perceptions of risk and travel intentions: The case of China and the Beijing Olympic Games. Journal of Sport \& Tourism, 14(1): 43-67.

Richter, L. K. (2003). International tourism and its global public health consequences. Journal of Travel Research, 41(4): 340-347

Rid, W., Ezeuduji, I. O. and Pröbstl-Haider, U. (2014). Segmentation by motivation for rural tourism activities in The Gambia. Tourism Management, 40: 102-116.

Ritcher, K. L. (2003). International tourism and its global public health consequences. Journal of Travel Research, 41: 340-347.

Rittichainuwat, B. N. and Chakraborty, G. (2009). Perceived travel risks regarding terrorism and disease: The case of Thailand. Tourism Management, 30(3): 410-418.

Shoemaker, S. (1994). Segmenting the US travel market according to benefits realized. Journal of Travel Research, 32(3): 8-21.

Sirakaya, E., McLellan, R. W. and Uysal, M. (1996). Modeling vacation destination decisions: A behavioral approach. Journal of Travel \& Tourism Marketing, 5(1-2): 57-75.

Steffen, R. deBernardis, C. and Banos, A. (2003). Travel epidemiology a global perspective. International journal of antimicrobial agents, 21(2): 89-95.

Svensson, P., Sundbeck, M., Persson, K. I., Stafström, M., Östergren, P. O., Mannheimer, L. and Agardh, A. (2018). A meta-analysis and systematic literature review of factors associated with sexual risk-taking during international travel. Travel Medicine and Infectious Disease, 24: 65-88.

Tavşancıl, E. (2005). Tutumların Ölçülmesi ve SPSS ile Veri Analizi. Ankara: Nobel Yayıncılık.

Tenekecioğlu, B. ve Ersoy, F. (2007). Pazarlama Yönetimi (No. 1478). Anadolu Üniversitesi.

Trindade, G., Dias, J. G. and Ambrósio, J. (2017). Extracting clusters from aggregate panel data: A market segmentation study. Applied Mathematics and Computation, 296: 277-288.

Uslu, S. (2017). Sürdürülebilir turizm kapsamında Kapadokya'ya gelen yabancı turistlerin Türkiye'ye bakışı ve güvenlik algısı. Yayınlanmamış Yüksek Lisans Tezi, Necmettin Erbakan Üniversitesi: Konya.

Waryszak, Z. R. And Kim, H. (1994). Psychographic segmentation of tourist as a predictor of their travel behaviour: an exploratory study of Korean tourists to Australia. Journal of Hospitality ELeisure Marketing, 2 (4): 5-19.

Wilder-Smith, A., Khairullah, N. S., Song, J. H., Chen, C. Y. and Torresi, J. (2004). Travel health knowledge, attitudes and practices among Australasian travelers. Journal of Travel Medicine, 11(1): 9-15.

Wind, Y. (1978). Issues and advances in segmentation research. Journal of Marketing Research, 15(3): 317-337. 
Wynberg, E., Toner, S., Wendt, J. K., Visser, L. G., Breederveld, D. and Berg, J. (2012). Business travelers' risk perception of infectious diseases: where are the knowledge gaps, and how serious are they? Journal of Travel Medicine, 20(1): 11-16.

Wyner, G. A. (1995). Segmentation analysis, then and now. A Magazine of Management $\mathcal{E}$ Applications, 7(1): 40-41.

Yannopoulos, P. and Rotenberg, R. (2000). Benefit segmentation of the near-home tourism market: The case of upper New York state. Journal of Travel \& Tourism Marketing, 8(2): 41-55.

Zhang, M., Liu, Z., He, H., Luo, L., Wang, S., Bu, H. and Zhou, X. (2011). Knowledge, attitudes, and practices on malaria prevention among Chinese international travelers. Journal of travel medicine, 18(3): 173-177.

Zimmermann, R., Hattendorf, J., Blum, J., Nüesch, R. and Hatz, C. (2013). Risk perception of travelers to tropical and subtropical countries visiting a swiss travel health center. Journal of Travel Medicine, 20(1): 3-1. 